Antioxidant Properties of Hydroxycinnamic Acids: A Review of Structure-Activity Relationships

N. Razzaghi-Asl, J. Garrido, H. Khazraei, F. Borges and O. Firuzi

\begin{abstract}
Hydroxycinnamic acids (HCAs) are important phytochemicals possessing significant biological properties. Several investigators have studied in vitro antioxidant activity of HCAs in detail. In this review, we have gathered the studies focused on the structure-activity relationships (SARs) of these compounds that have used medicinal chemistry to generate more potent antioxidant molecules. Most of the reports indicated that the presence of an unsaturated bond on the side chain of HCAs is vital to their activity. The structural features that were reported to be of importance to the antioxi- dant activity were categorized as follows: modifications of the aromatic ring, which include alterations in the number and position of hydroxy groups and insertion of electron donating or withdrawing moieties as well as modifications of the car- boxylic function that include esterification and amidation process. Furthermore, reports that have addressed the influence of physicochemical properties including redox potential, lipid solubility and dissociation constant on the antioxidant activ- ity were also summarized. Finally, the pro-oxidant effect of HCAs in some test systems was addressed. Most of the investigations concluded that the presence of ortho-dihydroxy phenyl group (catechol moiety) is of significant importance to the antioxidant activity, while, the presence of three hydroxy groups does not necessarily improve the activity. Optimiza- tion of the structure of molecular leads is an important task of modern medicinal chemistry and its accomplishment relies on the careful assessment of SARs. SAR studies on HCAs can identify the most successful antioxidants that could be use- ful for management of oxidative stress-related diseases.
\end{abstract}

Keywords: Antioxidant, hydroxycinnamic acids, in vitro, ROS, structure-activity relationships.

\section{OXIDATIVE STRESS AND ANTIOXIDANTS}

Reactive oxygen species (ROS) are oxygen derived molecules that readily react with other compounds and macromolecules and oxidize them. Some representative exam- ples of these species include superoxide $\left(\mathrm{O}_{2}{ }^{\circ-}\right)$, hydroxy $\left(\mathrm{HO}^{\circ}\right)$ and peroxy $\left(\mathrm{ROO}^{\circ}\right)$ radicals, hydrogen peroxide $\left(\mathrm{H}_{2} \mathrm{O}_{2}\right)$ and singlet oxygen $\left({ }^{1} \mathrm{O}_{2}\right)[1-4]$.

ROS are involved in important physiological processes such as immune response, gene expression, signal transduc- tion and growth regulation $[5,6]$; however if they are not kept under tight control by physiological antioxidant systems they will be able to oxidize and damage various biological molecules leading to a condition called oxidative stress $[1,7,8]$. In this regard, oxidative stress has been reported to be in- volved in the pathogenesis of diseases such as cancer [9], neurodegenerative diseases [10], stroke [11], and others [12,13].
Since an important source of ROS comes from environment [14], with the industrial development and the change in life style, oxidative stress related diseases need a special attention [15].

Antioxidants operate by preventing or slowing the progression of oxidative damage reactions [16, 17]. An antioxidant has been defined as "any substance that delays, prevents or removes reactive species capable of inducing oxidative damage to a target molecule" [1]. Another requirement is that the compound should also generate a more stable, and therefore less injurious, intermediate molecule upon reaction with a ROS in order to be considered as a good antioxidant [4]. With the recent findings, these definitions should be broadened to encompass also agents that are capable of sequestering transition metal ions (chelation activity), inhibi- tion of enzymes involved in ROS production and induction of endogenous defense mechanisms such as antioxidant enzymes [18].

Large scale epidemiologic cohort studies in different populations have provided evidence that consumption of dietary antioxidants is associated with reduced risks of heart diseases and neurodegeneration $[19,20]$. Although a number of interventional trials have failed to prove the usefulness of antioxidants for disease management, the use of disease spe- 

cific, target-directed antioxidants in carefully chosen patients with higher levels of oxidative stress may prove useful in management of certain diseases [14, 21, 22].

\section{ANTIOXIDANT ACTIVITY OF HYDROXYCIN- NAMIC ACIDS}

In the past few decades, dietary polyphenols, which are one of the most abundant classes of antioxidants in human diet, have received increasing attention [23, 24]. Phenolic acids are an important group of secondary plant metabolites with powerful antioxidant capacities [25-27]. These acids are usually divided in two main groups: benzoic acids, contain- ing seven carbon atoms ( $\mathrm{C} 6-\mathrm{C} 1)$ and cinnamic acids, consist- ing of nine carbon atoms (C6-C3) [28]. These natural com- pounds exist predominantly as hydroxybenzoic and hy-droxycinnamic acids (HCAs) that may occur either in their

free or conjugated forms. Several types of hydroxybenzoic acids and HCA have been identified in the human diet, and are believed to play important roles due to their abundance

\section{0}

and functional diversity [29-31].

HCAs have ubiquitous distribution in the plant kingdom [3237] and are abundantly found in tea leaves, coffee, red wine, various fruits, vegetables, and whole grains [32, 38, 39]. They have been categorized as structural and functional constituents of plant cell walls and also as bioactive ingredi- ents of the diet $[40,41]$.

HCAs possess a simple chemical backbone consisting of a phenylpropanoid structure (Fig. 1). Natural HCAs usually appear either as free forms or esters being its basic unit the quinic acid or the glucose molecule or as more more sophisticated derivatives such as dimer, trimer or mixed glycosidic forms in plants [35]. Para-coumaric acid, ferulic acid, sinapic acid, and caffeic acid (Fig. 1) are the most represen- tative HCAs.

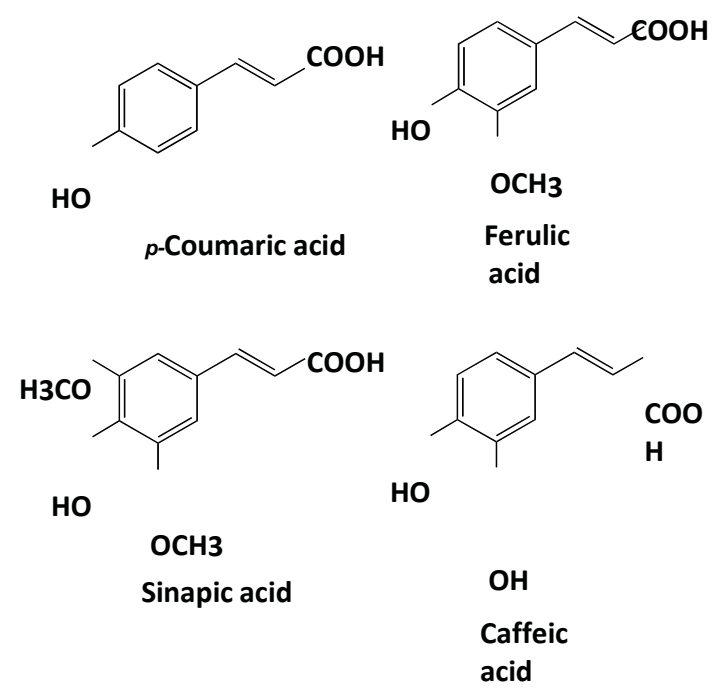

Fig. (1). Chemical structures of the major hydroxycinnamic acids.

HCAs and their derivatives have a broad spectrum of biological activities including antitumoral [42-45], antimicrobial [46], antioxidant [47-52] and neuroprotective effects [53-55].

One of the most important HCA derivatives is chloro- genic acid (CGA) which has been reported as an efficient antioxidant agent $[56,57]$.
(CQA) and dicaffeoylquinic acids (diCQA) represent the major CGAs found in nature [59].

CGAs are widely distributed in plant sources [60-62]. Coffee beans are one of the best dietary sources of CGA [59]. Moreover, CGAs possess a variety of biological activi- ties ranging from antifungal $[63,64]$, antiviral $[65,66]$ and neuroprotective $[67]$ to antidiabetic $[68,69]$ and cholesterol lowering [70] effects.

Another important caffeic acid derivative is caffeic acid phenethyl ester (CAPE) (Fig. 2). CAPE is an active compo- nent of propolis and has been reported to possess antimito- genic, anticarcinogenic, antiinflammatory, and immuno- modulatory properties [71].

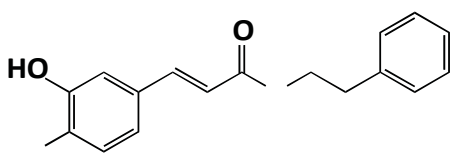

HO

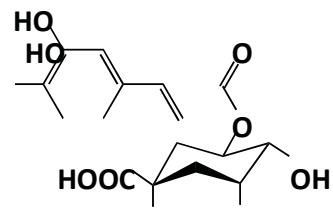

b $\mathrm{OH} \quad \mathrm{OH}$
Fig. (2). Chemical structures of a) caffeic acid phenethyl ester (CAPE) and b) chlorogenic acid (3-CQA).

Due to their structural similarity, several other polyphenols are considered as HCA analogs [72]. For instance, the phenylethanol derivatives, which comprise the 3,4-dihydroxy phenylethanol (hydroxytyrosol) and the 4-hydroxyphenyl ethanol (tyrosol), the curcumin and derivatives, such as yakuchinone $A$ and yakuchinone $B$, the capsaicin and dihydrocapsaicin and derivatives, rosmarinic acid and derivatives, [6]gingerol, [6]-paradol and derivatives are also considered as antioxidant components of diet and a natural inspiration for the development of new potent and effective antioxidants [7376].

A number of potential health benefits of the HCAs family have largely been connected to their antioxidant properties $[77,78]$. HCAs have been shown to be phytochemicals with remarkable antioxidant outlines they are able; a) to increase the resistance of low density lipoprotein (LDL) to lipid peroxidation $[56,79,80]$; b) to protect proteins against oxida- tion [81]; c) to chelate transition metals that catalyze oxida- tive reactions [82]; d) to scavenge a variety of ROS [47, 83-86]; e) to inhibit enzymes that are involved in oxidative stress [48,87].

Several in vitro antioxidant assays have been developed

Chlorogenic acids (CGAs) are esters of HCAs and quinic acid. The most common CGA is formed by esterification of caffeic acid to quinic acid (Fig. 2) [58]. Various isomers of CGAs in positions 3, (3-CQA), 4 (4-CQA) and 5 (5-CQA) of the quinic acid have been reported [58]. Caffeoylquinic acids 
for assessment of antioxidant activity (Table $\mathbf{1}$ ). Readers are advised to read to the relevant reviews to get more comprehensive view on the in vitro antioxidant methods [88-92].

RATIONAL DESIGN OF ANTIOXIDANTS; STRUC- TUREACTIVITY RELATIONSHIPS OF HYDROXY- CINNAMIC ACIDS

For decades, natural products have provided an invaluable source of novel lead structures for drug discovery [93]. In recent times, there has been renewed interest in natural products research, mostly motivated by the lower prevalence of undesired side effects of these compounds [23, 44, 94]. 
Table 1. Most Commonly Used In Vitro Antioxidant Assays

\begin{tabular}{|c|c|c|c|c|}
\hline No. & Method & Mechanism & Reference & Number of \\
\hline 1 & $\begin{array}{l}\text { Crocin bleaching } \\
\text { assay (CBA) }\end{array}$ & Crocin bleaches upon oxidation by free radicals & {$[163]$} & 83 \\
\hline 2 & $\begin{array}{l}\text { Cupric reducing } \\
\text { antioxi- dant capacity }\end{array}$ & $\begin{array}{l}\text { Copper(II)-neocuproine [Cu(II)-Nc] reagent used as the } \\
\text { chromogenic oxidiz- ing agent. }\end{array}$ & {$[164]$} & 101 \\
\hline 3 & $\begin{array}{l}\text { Ferric Reducing } \\
\text { Antioxi- dant Power }\end{array}$ & $\begin{array}{l}\text { Complex of Fe }{ }^{+2} \text {-TPTZ (tris-pyridyl-triazine) is reduced and } \\
\text { measured sner-tronhotometrically }\end{array}$ & {$[165]$} & 2720 \\
\hline 4 & $\begin{array}{l}\text { Oxygen radical } \\
\text { absor- bance }\end{array}$ & $\begin{array}{l}\text { Peroxyl radical is generated by AAPH and decrease in fluorescence } \\
\text { of a fluo- rescent probe is measured }\end{array}$ & {$[166]$} & 654 \\
\hline 5 & $\begin{array}{l}\text { Oxygen radical } \\
\text { absor- bance } \\
\text { capacitv fluo- }\end{array}$ & $\begin{array}{l}\text { An improved method of ORAC assay using fluorescein }\left(3^{\prime}, 6^{\prime}\right. \\
\text { dihydroxyspiro [isobenzofuran- } 1[3 H], 9^{\prime}[9 H] \text {-xanthen]-3-one) as the }\end{array}$ & {$[167]$} & 599 \\
\hline 6 & $\begin{array}{l}\text { Trolox equivalent } \\
\text { anti- oxidant capacity }\end{array}$ & 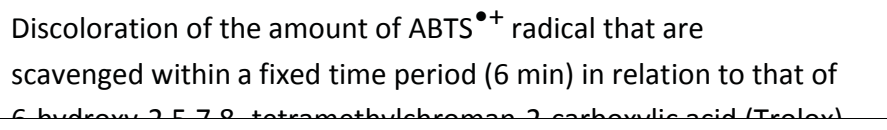 & {$[168]$} & 1350 \\
\hline 7 & $\begin{array}{l}\text { Total radical } \\
\text { trapping } \\
\text { antioxidant }\end{array}$ & $\begin{array}{l}\text { AAPH is used as generator of peroxyl radicals, while oxygen uptake, } \\
\text { fluores- cence of R-phycoerythrin, or absorbance of } \mathrm{ABTS}^{\bullet+} \text { are } \\
\text { mancurad to manitar avidation nmacoer }\end{array}$ & {$[169]$} & 329 \\
\hline 8 & ABTS assay & $\begin{array}{l}\text { ABTS }^{\bullet+} \text { radical cation has a characteristic color that is } \\
\text { measuredsnectronhototmetricallv }\end{array}$ & {$[170]$} & 3186 \\
\hline 9 & DPPH method & Spectrophotometric determination of stable free radical DPPH & $\begin{array}{l}{[171]} \\
{[172]}\end{array}$ & $\begin{array}{l}2946 \\
2275\end{array}$ \\
\hline 10 & $\begin{array}{l}\text { Hydroxyl radical } \\
\text { scav- enging }\end{array}$ & $\begin{array}{l}\text { Hydroxyl radical is generated by using } \mathrm{Fe}^{3+} \\
\text { /ascorbate/FDTA/ } \mathrm{H} 2 \mathrm{O} \text { 2 svstem wsine Fenton reaction }\end{array}$ & [173] & 574 \\
\hline 11 & $\begin{array}{l}\text { Hydrogen peroxide } \\
\text { scav- enging }\end{array}$ & The decrease in of $\mathrm{H}_{2} \mathrm{O}_{2}$ is measured spectrophotometrically & {$[174]$} & 1901 \\
\hline 12 & $\begin{array}{l}\text { Peroxynitrite } \\
\text { radical }\end{array}$ & $\begin{array}{l}\text { Monitoring the oxidation of dihydrorhodamine by peroxynitrite } \\
\text { radical on a microplate fluorescence spectrophotometer }\end{array}$ & {$[175]$} & 475 \\
\hline 13 & $\begin{array}{l}\text { Singlet oxygen } \\
\text { Scaveng- ing }\end{array}$ & $\begin{array}{l}\text { The decay rate of singlet oxygen phosphorescence at } 1270 \mathrm{~nm} \text { is } \\
\text { mancurad }\end{array}$ & [176] & $543^{*}$ \\
\hline 14 & $\begin{array}{l}\text { Superoxide anion } \\
\text { scav- enging activity }\end{array}$ & $\begin{array}{l}\text { Generation of superoxide anions enzymatically in a hypoxanthine- } \\
\text { xanthine oxidase system coupled with nitroblue tetrazolium } \\
\text { (NBT) reduction and measurement of the absorbance related to } \\
\text { the redurtion of nitrn hlue totra- } 70 \text { lium at } 5 \Delta \mathrm{nm}\end{array}$ & {$[177]$} & 3515 \\
\hline 15 & $\begin{array}{l}\text { /J-carotene linoleic } \\
\text { acid bleaching assay }\end{array}$ & Products of linoleic acid oxidation bleach $/ J$-carotene in the emulsion & [178] & 313 \\
\hline 16 & $\begin{array}{l}\text { Low-density } \\
\text { lipoprotein }\end{array}$ & $\begin{array}{l}\text { A gradual increase in absorbance due to formation of conjugated } \\
\text { dienes from oxidation of LDL is inhibited by antioxidants }\end{array}$ & [179] & 366 \\
\hline
\end{tabular}

${ }^{1}$ According to the Scopus databank Accessed October 2012. * Citations from Google Scholar.

AAPH: 2,2'-azobis(2-amidinopropane) dihydrochloride; $\mathrm{ABTS}^{\bullet+}$ : 2,2'-azinobis-(3-ethylbenzthiazoline-6-sulfonic acid); DPPH: 1,1-Diphenyl-2picrylhydrazyl.

As the design of antioxidant agents cannot rely on receptor-based drug design methods due to the lack of specific molecular targets efforts have been moved towards an analogue-based drug design approach. In fact, identification of molecular leads of natural origin and the optimization of their structure to enhance the activity against different targets is an important task of modern medicinal chemistry. The accomplishment of this task certainly relies on the establishment of structure-activity relationships (SARs), which is a valuable tool for discovery of more effective molecules [9597]. Much effort has been directed to the discovery of the ideal pharmacophore and the improvement of the activity in order to generate more potent antioxidants.

The main concept of SAR is that the biological activity of molecules could be attributed to their chemical structure and physico-chemical properties. Analysis of SAR enables the determination of the chemical functional groups respon- 
sible for providing a certain effect and allows medicinal chemists to modify the potency of a bioactive compound by changing its chemical structure. SAR analysis focused on natural compounds is of significant importance due to their evergrowing role in human health [98]. Several interesting SAR studies on naturally occurring substances are found in the literature $[35,56,99,100]$. Our particular interest, sev- eral SAR studies have been described that correlate struc- tural characteristics of HCAs to their in vitro radical scav- enging effects [101-103].

HCAs have two important structural features that make them an interesting scaffold: a) the presence of hydroxy functions on the benzene ring, which can produce a phenoxy radical intermediate that may terminate the free radical chain reaction [104]; b) the ethylenic side chain that contains unsaturated bond being able to stabilize the phenoxy radical or offer an additional site for reaction with ROS [104, 105] (Fig. 3).

The effect of the type of the spacer group between carboxyl moiety and the phenyl ring has been well established in terms of radical scavenging activity [52]. Our previous studies have uncovered the importance of this unsaturated side chain for the antioxidant activity [106], which could be ascribed to the participation of the double bond in stabilization of the phenoxy radicals via increased electron delocalization. However, its role is quite dependent of the type of HCAs, mainly of the substitution pattern of the aromatic moiety.

Studies performed on caffeic acid and its esterified and amidated derivatives demonstrated that the presence of $\mathrm{H}$ donating substituents such as $-\mathrm{NH}$ or $-\mathrm{SH}$ could also be responsible for the enhancement of the antioxidant activity of HCAs as a result of their hydrogen donating ability $[35,107]$.

In this paper, we have reviewed in vitro studies that have been focused on structure-antioxidant activity relationships of HCAs. In addition, the effect of HCAs physicochemical properties on their antioxidant performance has been also summarized.
The structural features that were of significant impor-tance in SARs of HCAs were divided to two subsections that include the modifications of the aromatic ring and the modi- fications of the carboxylic function.

\section{MODIFICATIONS OF THE AROMATIC RING}

\section{Number of Hydroxy Groups}

Antioxidant activity of HCAs seems to be largely influ- enced by the number of hydroxy groups present on the aro- matic ring $[83,108]$. This effect can be attributed to the fact that the phenoxy radical that is formed when HCA molecule is oxidized by ROS can be stabilized by the adjacent elec- tron-donating hydroxy groups $[56,83,109,110]$.

Moreover; molecules bearing ortho-dihydroxy or 4hydroxy-3-methoxyl groups possess higher antioxidant activ- ity than those bearing no such functionalities [101].

\section{Trihydroxy Versus Dihydroxy}

Increasing the number of hydroxy groups of HCAs usu- ally results in a higher in vitro antioxidant capacity in aque- ous systems. Several investigations have shown a higher antioxidant activity for trihydroxy (possessing pyrogallol moiety) compared to dihydroxy (possessing catechol moiety) and monohydroxy phenolic acids $[52,81,111]$.

We have also shown that 3-(3,4,5-trihydroxyphenyl) propenoic acid has better antioxidant profile than caffeic acid in ABTS and DPPH assays [52]. It should be noted that the order of efficiency may change in lipid peroxidation assays, and dihydroxylated acids may be more potent antioxidants than corresponding trihydroxylated compounds in these sys- tems $[52,112]$. Similar trend has been observed among fla- vonoids [113]. This is possible because the antioxidant activ- ity in membranes also depends on the lipophilicity of the compound [83] and in a more lipophilic media such as the matrix in lipid peroxidation assays, a higher number of phenolic groups may compromise the overall lipophilicity and cause a decrease of the antioxidant capacity $[52,83]$. Dihy- droxylated cinnamic acids possess higher lipophilicity,

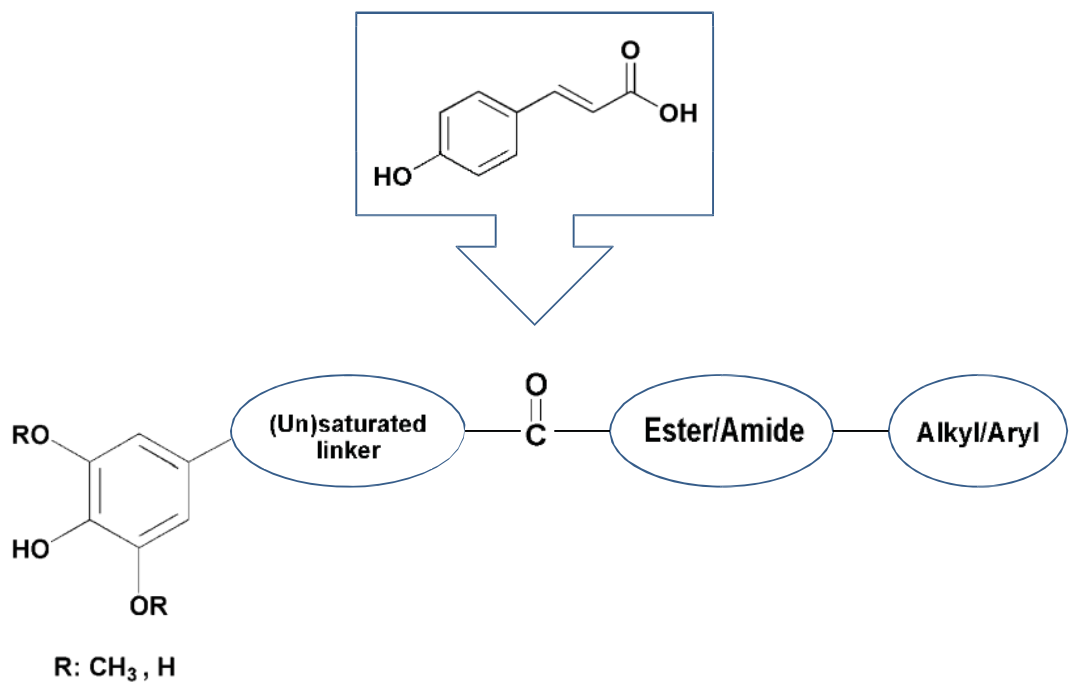

Fig. (3). Schematic representation of structural features of hydroxycinnamic acids that have been modified to improve their antioxidant activ- ity. 
measured by oil/water partition coefficient, compared to trihydroxylated cinnamic acids and this property could give them a better protective ability against lipid peroxidation [112]. However, it is important to point out that even in lipo- philic systems, in a condition of relatively equal lipophil- icities the determinant parameter could be the number of hydroxy groups [35].

\section{Dihydroxy Versus Monohydroxy}

Greater hypochlorite scavenging [47] and singlet oxygen quenching abilities [84] of caffeic acid (dihydroxy substi- tuted) over para-coumaric acid (monohydroxy substituted) have been previously reported. Also in ferrylmyoglobin- dependent LDL peroxidation assay the activity of HCAs is highly dependent on the number of hydroxy groups: ortho- dihydroxy derivatives (caffeic and chlorogenic acids) could act as efficient LDL peroxidation blocking agents when compared to para-coumaric acid [114]. The same trend was also observed when HCAs amides were compared; caffeic amides showed superior antioxidant activity compared to the corresponding paracoumaric amides in DPPH and micro- somal lipid peroxidation assays [115].

\section{Position of Hydroxy Groups}

The presence of a catecholic moiety seems to be of great importance to the antioxidant activity of HCAs [101, 103, 116119]. In this regard, two critical factors have been pro- posed emphasizing the antiradical activity of HCAs contain- ing catechol moiety bond dissociation energy of $\mathrm{O}-\mathrm{H}$ bond and ionization potential [52]. The $\mathrm{O}-\mathrm{H}$ bond dissociation energy is a function of presence of the electron-donating hydroxy group(s) at the ortho position [35]. This substitution pattern lowers the $\mathrm{O}-\mathrm{H}$ bond energy and enhances the rate of $\mathrm{H}$-atom abstraction from the molecule and hence generation of ortho-semiquinone radical anion or ortho-hydroxy phe- noxy radical (homodisproportionation). This species is more readily oxidized to a final ortho-quinone product.

Phenolic compounds bearing catechol behave as chainbreaking antioxidants. In a comparative study performed by Kancheva et al. [120], caffeic acid exhibited strongest antioxidant activity in various assays, such as lipid autooxidation and DPPH assay.

In crocin bleaching assay ( $C B A)$, the importance of the catechol moiety in providing high antioxidant capacity in HCAs has been demonstrated [100]. It was also emphasized that the positive impact of a catechol moiety could be attrib- uted to the ease of $\mathrm{H}$-atom abstraction from either 3- or 4- $\mathrm{OH}$ group leading to the formation of stable semiquinone radicals [100].

It has also been shown recently that radical scavenging ability against DPPH and ABTS radicals is lower for dimethoxycinnamic acid and (E)-2-(3-(3,4-dimethoxyphenyl) prop-2-enamido) ethyltriphenylphosphonium methanesulfonate compared to compounds possessing a catechol group [121].

\section{Ortho-Phenolic HCAs Form Intramolecular Hydrogen Bonding}

Another distinguished feature of ortho-hydroxy substituents is their ability to form intramolecular H-bonds [52, 122].
It was spectrophotometrically demonstrated that the intermediate phenoxy radical arising from molecules with orthohydroxy groups would be efficiently stabilized owing to the intramolecular hydrogen bonding $[49,123]$.

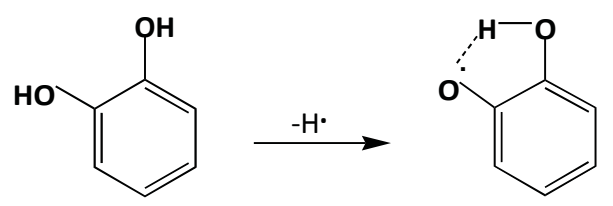

Fig. (4). Intramolecular hydrogen bond that is generated in a hy- droxycinnamic acid molecule bearing catechol moiety after hydro- gen abstraction.

\section{Introduction of Electron Donating Substituents}

Castelluccio et al. [111] reported that the antioxidant potency of para-coumaric acid against autooxidation of methyl linoleate is dramatically enhanced by insertion of a methoxy group in the ortho position to the hydroxy group (as in the structure of ferulic acid Fig. 1). The authors postulated that the enhancement of activity is related to the electron- donation properties of the methoxy moiety that can stabilize the phenoxy radical formed in the reaction with free radicals. The superior activity of ferulic acid compared to para- coumaric acid has been observed also by other authors [47, 124, 125]. Addition of the second methoxy group (as in the structure of sinapic acid Fig. 1) further increases the activity, as deducted from the comparison of sinapic acid with ferulic acid in hypochlorite scavenging [47] and DPPH scavenging assays [125, 126]. Similarly, the results of our group and others have demonstrated that esters of sinapic acid are more active than esters of ferulic acid in -carotene-linoleic acid system [127] and in DPPH assay [126]. In a studty on the kinetics of lipid peroxidation in the presence of HCAs, sinapic acid ensured a longer oxidation stability of lipids when compared to ferulic and para-coumaric acid [128]. The higher stability of phenoxy radicals being surrounded by two methoxy groups rather than one, have been also exploited via combined kinetic and EPR studies [129].

However, when caffeic acid (3,4-dihydroxycinnamic acid) is compared to ferulic acid (3-methoxy-4- hydroxycinnamic acid), the presence of a methoxy substitu- ent usually decreases the activity [47, 130]. For instance, Wu et al. [83] have reported that ferulic acid and ethyl ferulate were less efficient than caffeic acid and caffeic acid phenethyl ester in scavenging DPPH and galvinoxyl radicals as the result of methoxylation of 3-hydroxy group and the absence of formation of quinone oxidation products.

Other investigators have reported that the performance of the isomers is quite different: 3-hydroxy-4-methoxy (isoferulic acid) is 3-4 folds less efficient than 3-methoxy-4- hydroxy (ferulic acid) in crocin bleaching assay [100].

\section{Introduction of Electron Withdrawing Substituents}

There is a paucity of data on the influence of electron withdrawing substituents on the antioxidant activity of HCAs. 3-Nitro-4-hydroxycinnamic acid has been found as a secondary metabolite of marine Vibrio strain from the Red Sea [131]. However, some preliminary studies have 
shown that the presence of bromine electron withdrawing group at the ortho position to the hydroxy group of HCAs has no effect on the antioxidant activity [82].

Iwasaki et al. [132] synthesized a nitrated chlorogenic acid (CGA) and demonstrated that it had stronger antioxidant activity than non-nitrated CGA. The observed effects were attributed to the higher ability of nitrocatechol derivatives in sequestering chelated iron compared to catechol. These researchers postulated that nitrated phenolic compounds can bind to metal ion and prevent the generation of hydroxy radical. Del prete et al. [133] have demonstrated that 2- cyano4-hydroxycinnamic acid inhibited glucose oxidation. More studies are required to investigate the effect of this type of substituents on the antioxidant activity.

\section{MODIFICATIONS OF THE CARBOXYLIC FUNC- TION}

\section{Esterification}

Biological properties of HCA ester derivatives have gained much attention and several SAR studies have investi- gated the effect of esterification on the antioxidant activity of these compounds (Table 2). The effect of esterification on the antioxidant activity of HCAs seems to be dependent on the type of cinnamic acid as well as the ester [126]. It has been found that ester derivatives of caffeic acid possessed stronger biological activity as compared to caffeic acid, ferulic acid and even synthetic Trolox compound in AAPH- induced lipid peroxidation of Tween-emulsified linolenic acid [35]. Petrucci et al. [134] have suggested that the oxida- tion product of ethyl caffeate (o-quinone) is more stable than the oxidation products of unesterified HCAs (phenoxy radi- cal). The more stable intermediates of esters may explain their higher antioxidant activity in many test systems. Table $\mathbf{2}$ summarize some of the effects on the antioxidant activity of corresponding HCAs as the result of side chain esterifica- tion.

\section{Esterification Increases the Lipophilicity}

Several HCA esters have been synthesized as antioxi- dants (Table 2). Ester bond increases lipid solubility of a compound [55] and therefore, alkyl hydroxycinnamates have proven to be efficient ROS scavengers in lipophilic systems [126].

We have previously observed that esterification with short chain (methyl, ethyl, propyl and butyl) alkyls slightly lowered the antioxidant activity of sinapic acid in DPPH and FRAP assays but it had a positive effect on the partition co- efficient that could extend the utility of this compound as an antioxidant in more lipophilic media [86]. Similar findings were reported about methyl to dodecyl esters of ferulic acid; the DPPH scavenging effect of the esters was decreased when compared to the parent compound, but their activity in more lipophilic media was considerably increased [125]. In a microsomal lipid peroxidation inhibition assay, ferulic acid was found to be more potent than ethyl ferulate in homoge- neous phase; however, it was almost inactive in heterogene- ous phase of microsomes [83]. It has also been proposed that esterified derivatives of cinnamic acids can be used as ap- propriate radical scavenging agents for bulk oil systems due to their increased lipophilicities [135].

\section{Amidation}

Synthesis of amide derivatives of HCAs have been a strategy followed by several groups due to the improved in vivo stability and solubility of these derivatives $[35,115,136$, 137]. Since esters of HCA may be hydrolyzed by some colonic bacteria [138], it has been suggested that am-ides may have the advantage of being more suitable for oral use [115].

Several studies can be described in which different types of HCAs amides were synthesized and the antioxidant activ- ity evaluated:

a) Hung et al. [139] developed a series of substituted anilides of caffeic acid (Fig. 5). It was shown that all the compounds as well as caffeic acid itself, exhibit an antioxi- dant activity higher than standard antioxidants (Trolox and vitamin E) in DPPH and ABTS assays. Moreover, the phenethyl amide of caffeic acid displayed a higher antioxi- dant capacity compared to the analogous caffeic ester deriva- tive, in DPPH assay [35].

An increment of the radical scavenging activity via increasing the number of hydroxyl groups in the phenethyl ring has also been observed [35], an effect that is related with the contribution of amide bond in stabilizing the intermediate radicals. A paradoxical behavior was recorded in an in vitro model using AAPH-induced lipid peroxidation of Tweenemulsified linolenic acid in which phenethyl ester of caffeic acid exerted a higher antioxidant activity than the corre- sponding amide derivative [35].

b) Efforts toward synthesis of new HCA amides bearing a thiazole containing amino acid led to the compounds exhibiting better in vitro antioxidant activity than the valine containing thiazole in a DPPH assay (Fig. 6) [140]. 3).

Effects of amidation in HCAs are summarized in (Table

Oxidative decomposition of lipids is an adverse reaction leading to harmful health effects [141]. Lipid hydroperoxides (LOOH) may break down into free radicals, which are responsible for subsequent autoxidation reactions. In this regard, phenolic compounds and their derivatives are very efficient substances in avoiding autooxidation processes [128]. For instance, CGA was found to protect human erythrocytes from oxidative stress produced by low levels of lipid hydroperoxides in artificial liposomes [142]. Kortenska et al. [128] investigated the kinetics of lipid peroxidation in the presence of cinnamic acid derivatives. For this purpose, the triacylglycerols of sunflower oil were used as lipid samples in lipid oxidation model. This study revealed that the free carboxylic group $(\mathrm{COOH})$ in the structure of HCAs may negatively affect the kinetics of lipid oxidation.

\section{Effect of Physicochemical Properties on the Antioxidant Activity of Hydroxycinnamic Acids}

There are several reports which emphasize on the role of physicochemical variables in radical scavenging activity of HCAs $[35,52,82,109,143]$. Some of the most important physicochemical parameters will be discussed here. 

Table 2. Effect of Esterification of Hydroxycinnamic Acids, Carboxylic Function on the Antioxidant Activity

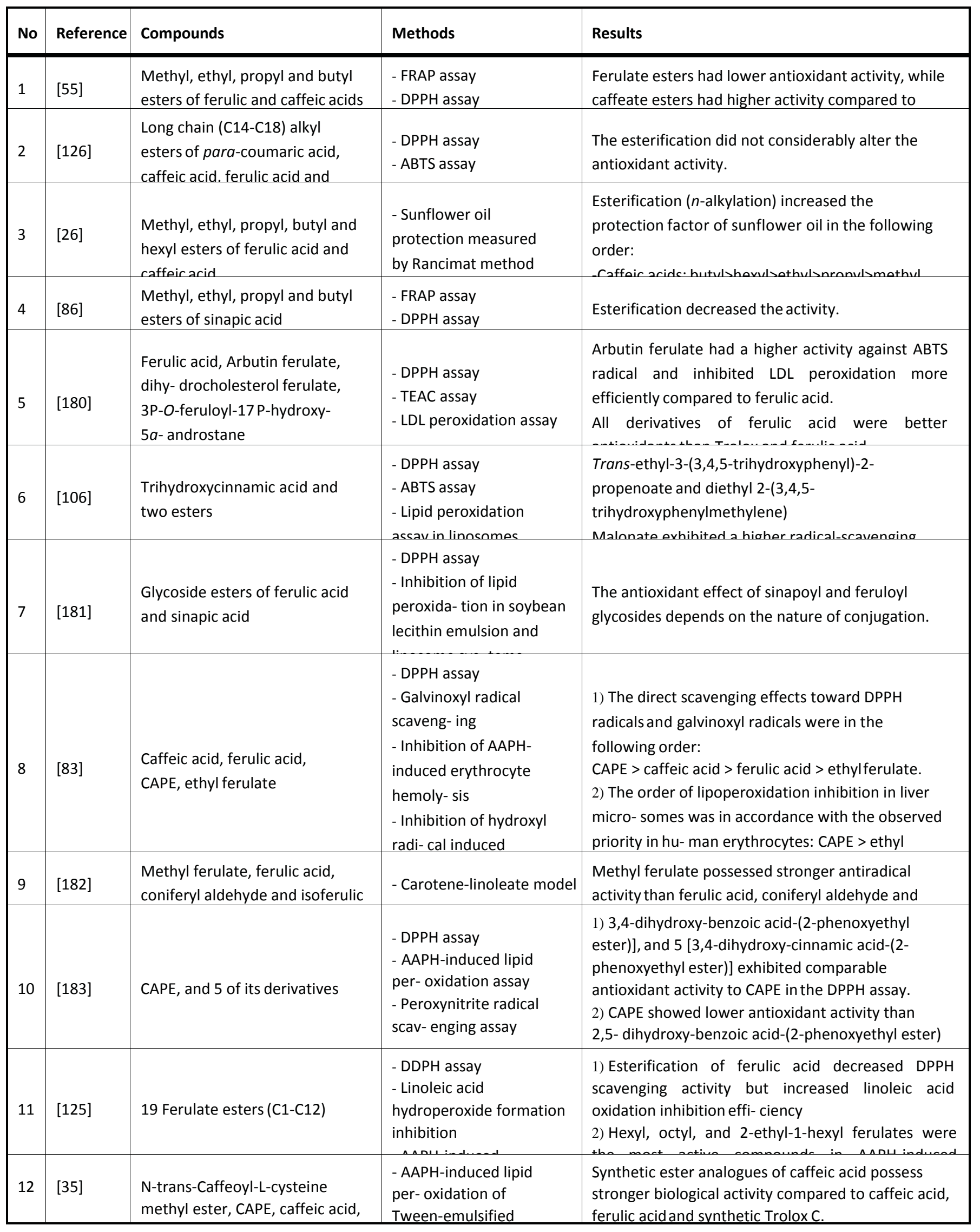


(Table 2) contd....

\begin{tabular}{|c|c|c|c|c|}
\hline No & Reference & Compounds & Methods & Results \\
\hline 13 & [184] & $\begin{array}{l}\text { Caffeic acid, sinapic acid, ferulic } \\
\text { acid and their ethyl esters }\end{array}$ & $\begin{array}{l}\text { - Copper-induced low- } \\
\text { density lipoprotein } \\
\text { (IDI) oxidation }\end{array}$ & $\begin{array}{l}\text { Ethyl esterification increased lipophilicity and } \\
\text { antioxidant properties of caffeic, sinapic and }\end{array}$ \\
\hline 14 & [185] & $\begin{array}{l}\text { Propyl esters of caffeic acid, } \\
\text { hydro- caffeic acid, ferulic acid, } \\
\text { isoferulic acid and gallic acid }\end{array}$ & $\begin{array}{l}\text { - Sunflower oil } \\
\text { protection measured } \\
\text { by Rancimat method } \\
\text { - DPPH assav }\end{array}$ & $\begin{array}{l}\text { A chain-breaking mechanism was proposed for } \\
\text { propyl es- ters. }\end{array}$ \\
\hline 15 & [109] & $\begin{array}{l}\text { Caffeic acid, methyl caffeate, } \\
\text { ethyl caffeate, propyl caffeate }\end{array}$ & - DPPH assay & $\begin{array}{l}\text { Esters of caffeic acid exhibited similar potencies } \\
\text { and were superior to caffeic acid. }\end{array}$ \\
\hline 16 & [186] & $\begin{array}{l}\text { Caffeic acid, caftaric acid, } \\
\text { chloro- genic acid, } \\
\text { neochlorogenic acid,ferulic, } \\
\text { fertaric acid, para-coumaric }\end{array}$ & $\begin{array}{l}\text { - Human LDL } \\
\text { oxidation assay }\end{array}$ & $\begin{array}{l}\text { 1) Esterification to tartaric acid slightly increased } \\
\text { the anti- oxidant activity of para-coumaric and } \\
\text { ferulic acids } \\
\text { 2) Esterification of caffeic acid to quinic acid (as in }\end{array}$ \\
\hline
\end{tabular}

AAPH: 2,2'-azobis(2-amidinopropane) dihydrochloride; ABTS $^{\bullet+}:$ 2,2'-azinobis-(3-ethylbenzthiazoline-6-sulfonic acid); CAPE: Caffeic acid phenethyl ester; DPPH: 1,1-Diphenyl-2- picrylhydrazyl; FRAP: Ferric Reducing Antioxidant Power; LDL: Low density lipoprotein.<smiles>[R]c1cccc(NC(=O)/C=C/c2ccc(O)c(O)c2)c1</smiles>

Fig. (5). General structures of caffeic acid anilides.

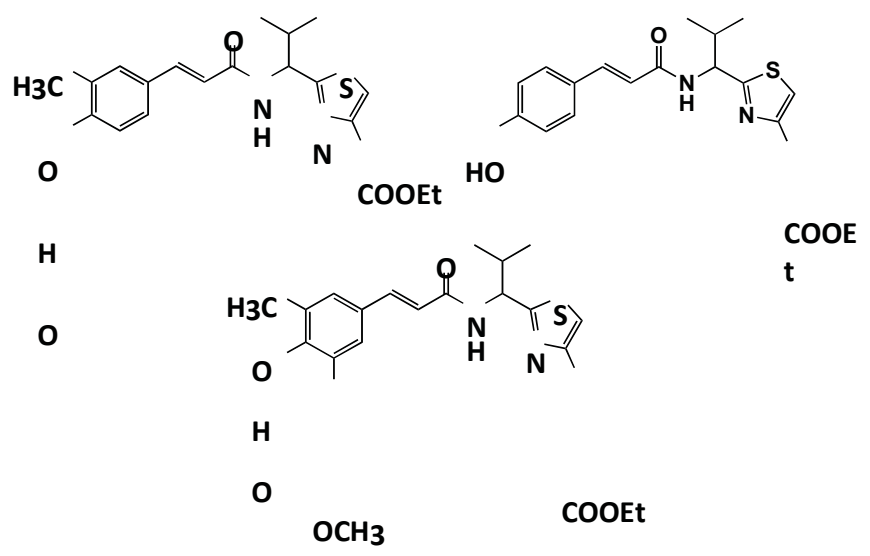

Fig. (6). Chemical structures of thiazole containing amino acidbased HCA amides.

\section{Redox Potential}

Electrochemical techniques provide powerful tools for the study of electron transfer in oxidation reactions and pro- vide useful information about the reaction mechanisms as well as intermediates. The use of cyclic voltammetry as an instrumental tool for the evaluation of the total antioxidant capacity of the low-molecular-weight antioxidants in in vitro systems is also well known [144, 145].

For a variety of natural and synthetic compounds, good correlations exist between antioxidant activity and oxidation potentials [146]. HCAs exert their antioxidant effects via activity of different molecules [146]. Studies performed by our group and others on synthesized and natural HCAs have demonstrated that redox potential is closely related with the in vitro antioxidant activity of HCAs [82, 135]. Differential pulse and cyclic voltammetry techniques have revealed that the structural characteristics of HCAs may influence the reduction-oxidation potential [121].

Our SAR studies on a set of synthesized HCAs including caffeic acid, ferulic and related compounds have shown that

derivatives with higher antioxidant efficacy (including caffeic acid and related compounds) have lower redox potential and those with lower antioxidant capacity (including ferulic acid and related derivatives) are associated with higher redox potentials [147]. We have also observed that methoxylation of ferulic acid leads to an increase in redox potential and a decrease in the antioxidant activity [82]. Other investigators

have similarly reported that the reduction potential of HCAs is inversely correlated with their quenching ability of singlet reduction (electron transfer) of ROS and knowledge on their inherent oxidation ability could be obtained by the study of their redox potentials [134]. Various reports have indicated that redox potentials can provide an index of antioxidant 
molecular oxygen [84].

\section{Lipid Solubility}

The antioxidant capacity of compounds per se does not predict the ability to protect cells exposed to oxidative their stress $[121,148]$. Lipophilic antioxidants can penetrate cell membranes and may prevent oxidative damage to cells through membrane-related partitioning effects that supplement their chemical activities [121]. Compounds possessing sufficient lipophilic character would also be able to cross the blood-brain barrier (BBB) and hence act as potential radical scavenging agents for protection against oxidative stress in the central nervous system [147]. On the other hand, inefficiency of dietary HCAs in relieving neuronal oxidative stress has been related mainly to their inability to pass through BBB [149]. Therefore, lipophilicity remains as one of the most important physicochemical variables in developing efficient radical scavenging agents. 
Table 3. Effect of Amidation of Hydroxycinnamic Acids, Carboxylic Function on the Antioxidant Activity

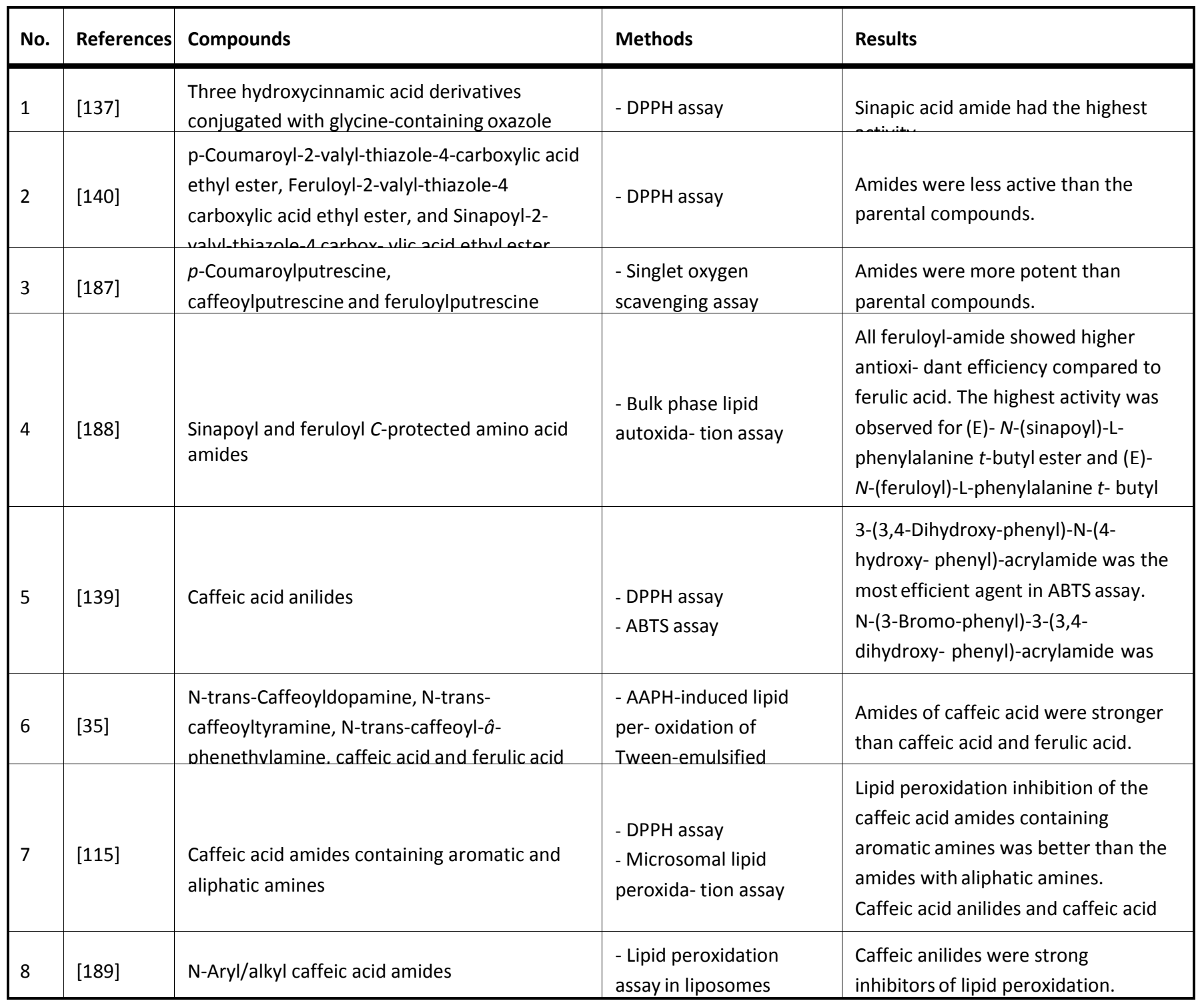

AAPH: 2,2'-azobis(2-amidinopropane) dihydrochloride; ABTS ${ }^{\bullet+}: 2,2^{\prime}$-azinobis-(3-ethylbenzthiazoline-6-sulfonic acid); CAPE: Caffeic acid phenethyl ester; DPPH: 1,1-Diphenyl-2- picrylhydrazyl; FRAP: Ferric Reducing Antioxidant Power; LDL: Low density lipoprotein.

On the other hand, one main restriction to the formulation of HCAs into food or cosmetic products is their hydrophilic character, which makes it difficult to integrate them into fat or oil matrices [82].

A way of increasing the lipophilicity of HCA molecules is the preparation of ester and amide derivatives [126], which facilitates their penetration through membranes and may also make them more suitable to be formulated into topical and skin preparations.

\section{Dissociation Constant}

Dissociation constant of HCAs also plays an important role in the antioxidant profile in various in vitro and in vivo systems [147]. In fact, the acidity of the phenolic moiety in HCAs may be affected by the electron donating/withdrawal nature of different substituents [109].
We have used the potentiometric method to determine the dissociation constants of caffeic acid, dihydrocaffeic acid and their methyl, ethyl and propyl esters and have observed that pKa values (para-OH) were lower for caffeic acid de- rivatives [109].

\section{Chelation Activity of Hydroxycinnamic Acids}

Transition metals play a very important role in generation of oxygen free radicals within the body of living organisms leading to lipid peroxidation, protein modification and DNA damage [150]. Hence metal sequestering agents may poten- tially protect the harmful effects of metal ions. In this regard, one of the preventive antioxidative mechanisms for HCAs may be metal chelation, i.e. formation of complexes with the metal ions [141, 151].

Some studies dealt with the complexation of metal ions with caffeic acid in various media and have been reported in the literature [152]. Psotova et al. [153] studied the chelation 
ability of ferulic, chlorogenic and caffeic acids with $\mathrm{Cu}(\mathrm{II}), \mathrm{Fe}(\mathrm{II})$ and $\mathrm{Fe}$ (III) ions using phosphate buffer-saline solu- tions mimicking reaction conditions used for cell culture experiments. Two types of complexes were detected with the stoichiometry of metal : ligand of = $1: 1$ and $1: 2$, while both complex types were stable. Caffeic acid did not form any complex with ferric ions, while trans-ferulic acid did not exhibit chelation activity at all.

In another report, chlorogenic acid was described to be efficient in forming a stable complex with $\mathrm{Fe}$ (II) ions. Chlorogenic acid and caffeic acid exhibited better chelation activity when compared to hydroxybenzoic acids [150]. The authors emphasized the importance of ortho-dihydroxy (catecholic) moiety in efficient binding to the metal ions. Compounds without catechol groups did not exhibit any complex formation. However, the place of chelation may be dependent on the metal ion, since Kalinowska et al. [154] synthesized manganese (II), copper (II) and cadmium (II) complexes of para-coumaric acid and characterized them with elemental and thermogravimetric analysis. The pro- posed binding site for these bidentate metal ions was the carboxylate moiety of para-coumaric acid.

\section{Pro-oxidant Effects of Hydroxycinnamic acids}

HCAs may act as pro-oxidants under certain circum-stances [155]. Some results supported the hypothesis that anticancer mechanism of plant polyphenols involved mobili- zation of endogenous copper and consequent pro-oxidant action [156, 157].

HCAs have the ability to act as pro-oxidants in systems containing redox-active metals [158, 159]. Redox cycling of HCAs can be catalyzed by transition metals in the presence of oxygen, producing organic radicals along with ROS that may damage biological macromolecules [160].

A study on different model systems containing i sh lipids showed that the pro-oxidative effect of caffeic acid in food emulsions and liposomes is highly dependent on the $\mathrm{pH}$, the applied emulsii er and type of prooxidants present [161]. The obtained results proved that caffeic acid can act as a prooxidant agent in the presence of $\mathrm{Fe}(\mathrm{II})$.

Maurya et al. [162] indicated that the antioxidant or prooxidant effect of ferulic acid and caffeic acid may depend on their concentration; these compounds show high antioxidant potential at lower concentrations, while exhibiting pro- oxidant behavior at higher concentrations. The pro-oxidant activity of ferulic acid and caffeic acid was attributed to their iron reducing properties [162].

\section{CONCLUDING REMARKS}

Much effort has been directed to the improvement of the activity of HCAs in order to generate more potent antioxidants. There is an inherent difficulty in choosing an appropriate antioxidant assay method, because various methodologies provide different findings according to the applied tar-get, probe and test conditions. In this regard, the use of a battery of in vitro assays that use dissimilar conditions may provide more reliable outcomes.
In general, the presence of the catechol moiety on the ring that has a role in stabilization of phenoxy radical as well as a double bond on the side chain that confers increased electron delocalization are the two most consistent structural properties that help improve the antioxidant profile in SAR studies. Certain esters such as caffeic acid phenethyl ester (CAPE) and chlorogenic acids (CGAs) have improved prop- erties compared to parent compounds, however, in general, esterification or amidation have various effects on the activ- ity of HCAs, which depends on the type of HCA, applied assay and also the type of ester or amide. Lipophilicity is generally increased due to esterification and amidation, which increases the antioxidant capacity in lipophilic sys- tems.

Finally, physicochemical properties of HCAs should also be taken into consideration in order to generate more feasible antioxidants for biological systems. SAR studies are very useful in providing a series of highly potent antioxidants that could be useful for management of oxidative stress-related diseases.

\section{CONFLICT OF INTEREST}

The authors confirm that this article content has no conflicts of interest.

\section{ACKNOWLEDGEMENTS}

The authors wish to thank the support of Shiraz Univer- sity of Medical Sciences, Vice-chancellor for Research, Iran.

\section{ABBREVIATIONS}

$\begin{array}{ll}\text { AAPH } & =\begin{array}{l}2,2 \text {-azobis(2-amidinopropane) hydrochlo- } \\ \text { ride }\end{array} \\ \text { ABTS } & =\begin{array}{l}2,2 \text {-azinobis(3-ethylbenzothiazoline-6- } \\ \text { sulfonic acid) }\end{array} \\ \text { CAPE } & =\text { Caffeic acid phenethyl ester } \\ \text { CBA } & =\text { Crocin bleaching assay } \\ \text { CGAs } & =\text { Chlorogenic acids } \\ \text { CQA } & =\text { Caffeoylquinic acid } \\ \text { CUPRAC } & =\text { Cupric reducing antioxidant capacity } \\ \text { LDL } & =\text { Low density lipoprotein } \\ \text { DPPH } & =1,1-\text { Diphenyl-2-picrylhydrazyl } \\ \text { FRAP } & =\text { Ferric reducing antioxidant power } \\ \text { HCA } & =\text { Hydroxycinnamic acid } \\ \text { ORAC } & =\text { Oxygen radical absorbance capacity } \\ \text { ROS } & =\text { Reactive oxygen species } \\ \text { RAE } & =\text { Relative antioxidant efficiency } \\ \text { SAR } & =\text { Structure-activity relationship } \\ \text { TAC } & =\text { Total antioxidant capacity } \\ \text { TEAC } & =\text { Trolox equivalent antioxidant capacity } \\ \text { TRAP } & =\text { Total radical trapping antioxidant parame- } \\ & \end{array}$




\section{REFERENCES}

[1] Halliwell, B.; Gutteridge, J.M.C. Free Radicals in Biology and Medicine, Oxford University Press, USA, 2007.

[2] Hensley, K.; Floyd, R.A. Reactive oxygen species and protein oxidation in aging; a look back, a look ahead. Arch. Biochem. Bio- phys., 2002, 397(2), 377-383.

[3] Albers, D.S.; Beal, M.F. Mitochondrial dysfunction and oxidative stress in aging and neurodegenerative disease. $J$. Neural. Transm., 2000, 59, 133-154.

[4] Hermans, N.; Cos, P.; Maes, L.; De Bruyne, T.; Vanden Berghe, D.; J Vlietinck, A.; Pieters, L. Challenges and pitfalls in antioxidant research. Curr. Med. Chem., 2007, 14(4), 417430.

[5] Vanhoutte, P.M. How we learned to say no. Arterioscler. Thromb.

Vasc. Biol., 2009, 29(8), 1156-1160.

[6] Bedard, K.; Krause, K.H. The NOX family of ROS-generating NADPH oxidases: physiology and pathophysiology. Physiol. Rev., 2007, 87(1), 245-313.

[7] Valko, M.; Rhodes, C.J.; Moncol, J.; Izakovic, M.; Mazur, M. Free radicals, metals and antioxidants in oxidative stressinduced cancer. Chem. Biol. Interact., 2006, 160(1), 1-40.

[8] Sies, H. Oxidative stress: oxidants and antioxidants. Exp. Physiol.,

1997, 82(2), 291-295

[9] Halliwell, B. Oxidative stress and cancer: have we moved forward?

Biochem. J., 2007, 401, 1-11.

[10] Perry, G.; Nunomura, A.; Hirai, K.; Zhu, X.; Prez, M.; Avila, J.; Castellani, R.J.; Atwood, C.S.; Aliev, G.; Sayre, L.M. Is oxidative damage the fundamental pathogenic mechanism of Alzheimer's and other neurodegenerative diseases? Free Radic. Biol. Med., 2002, 33(11), 1475-1479.

[11] Heo, J.H.; Han, S.W.; Lee, S.K. Free radicals as triggers of brain edema formation after stroke. Free Radic. Biol. Med., 2005, 39(1), 51-70.

[12] Firuzi, O.; Fuksa, L.; Spadaro, C.; Bousovà, I.; Riccieri, V.; Spadaro, A.; Petrucci, R.; Marrosu, G.; Saso, L. Oxidative stress parameters in different systemic rheumatic diseases. J. Pharm. Pharmacol., 2006, 58(7), 951-957.

[13] Hill, M.F. Emerging role for antioxidant therapy in protection against diabetic cardiac complications: experimental and clinical evidence for utilization of classic and new antioxidants. Curr. Car-diol. Rev., 2008, 4(4), 259.

[14] Firuzi, O.; Miri, R.; Tavakkoli, M.; Saso, L. Antioxidant therapy: current status and future prospects. Curr. Med. Chem., 2011, 18(25), 3871-3888.

[15] Romieu, I.; Castro-Giner, F.; Kunzli, N.; Sunyer, J. Air pollution, oxidative stress and dietary supplementation: a review. Eur. Respir. J., 2008, 31(1), 179-197.

[16] Cos, P.; Hermans, N.; Calomme, M.; Maes, L.; Bruyne, T.; Pieters, L.; Vlietinck, A.J.; Berghe, D.V. Comparative study of eight well- known polyphenolic antioxidants. J. Pharm. Pharmacol., 2003, 55(9), 1291-1297.

[17] Lorenz, P.; Zeh, M.; Martens-Lobenhoffer, J.; Schmidt, H.; Wol- fand, G.; Horn, T.F.W. Natural and newly synthesized hydroxy-1- aryl-isochromans: a class of potential antioxidants and radical scavengers. Free Radic. Res. Commun., 2005, 39(5), 535-545.

[18] Scapagnini, G.; Vasto, S.; Abraham, N.G.; Caruso, C.; Zella, D.; Fabio, G. Modulation of Nrf2/ARE pathway by food polyphenols: a nutritional neuroprotective strategy for cognitive and neurode- generative disorders. Mol. Neurobiol., 2011, 44(2), 192-201.

[19] Huxley, R.R.; Neil, H.A. The relation between dietary flavonol intake and coronary heart disease mortality: a meta-analysis of pro- spective cohort studies. Eur. J. Clin.
Nutr., 2003, 57(8), 904-908.

[20] Engelhart, M.J.; Geerlings, M.I.; Ruitenberg, A.; van Swieten, J.C.; Hofman, A.; Witteman, J.C.; Breteler, M.M. Dietary intake of anti- oxidants and risk of Alzheimer disease. JAMA, 2002, 287(24), 3223-3229.

[21] Willcox, B.; Curb, J.D.; Rodriguez, B.L. Antioxidants in cardiovascular health and disease: key lessons from epidemiologic stud- ies. Am. J. Cardiol., 2008, 101(10A).

[22] Pocernich, C.B.; Lange, M.L.; Sultana, R.; Butterfield, D.A. Nutritional approaches to modulate oxidative stress in Alzheimer's dis- ease. Curr. Alzheimer Res., 2011, 8(5), 452469.

[23] Ndhlala, A.R.; Moyo, M.; Van Staden, J. Natural antioxidants: fascinating or mythical biomolecules? Molecules 2010, 15, $6905-$

6930. 
[24] Han, X.; Shen, T.; Lou, H. Dietary polyphenols and their biological significance. Int. J. Mol. Sci., 2007, 8, 950-988.

[25] Sroka, Z.; Cisowski, W. Hydrogen peroxide scavenging, antioxi- dant and anti-radical activity of some phenolic acids. Food Chem. Toxicol., 2003, 41(6), 753-758.

[26] Merkl, R.; Hrádková, I.; Fillp, V.; Smidrkal, J. Antimicrobial and antioxidant properties of phenolic acids alkyl esters. Czech J. Food Sci., 2010, 28(4), 275-279.

[27] Kim, K.H.; Tsao, R.; Yang, R.; Cui, S.W. Phenolicacid profiles and antioxidant activities of wheat bran extracts and the effect of hy- drolysis conditions. Food Chem., 2006, 95(3), 466-473.

[28] Awika, J.M.; Rooney, L.W. Sorghum phytochemicals and their potential impact on human health. Phytochemistry, 2004, 65(9), 1199-1221.

[29] Khadem, S.; Marles, R.J. Monocyclic phenolic acids; hydroxyand polyhydroxybenzoic acids: occurrence and recent bioactivity sudies. Molecules, 2010, 15, 7985-8005.

[30] Scalbert, A.; Williamson, G. Dietary intake and bioavailability of polyphenols. J. Nutr., 2000, 130, 2073S-2085S.

[31] Psomiadou, E.; Tsimidou, M. Stability of virgin olive oil. 1. autoxidation studies. J. Agric. Food Chem., 2002, 50, 716721.

[32] Clifford, M.N. Chlorogenic acids and other cinnamatesnature, occurrence and dietary burden. J. Sci. Food Agr., 1999, 79(3), 362- 372.

[33] Bravo, L. Polyphenols: chemistry, dietary sources, metabolism, and nutritional significance. Nutr. Rev., 1998, 56(11), 317-333.

[34] Herrmann, K.; Nagel, C.W. Occurrence and content of hydroxy- cinnamic and hydroxybenzoic acid compounds in foods. CRC Crit. Rev. Food Sci. Nutr., 1989, 28(4), 315347.

[35] Son, S.; Lewis, B.A. Free radical scavenging and antioxidative activity of caffeic acid amide and ester analogues: structure-activity relationship. J. Agric. Food Chem., 2002, 50(3), 468-472.

[36] Barberousse, H.; Roiseux, O.; Robert, C.; Paquot, M.; Deroanne, C.; Blecker, C. Analytical methodologies for quantification of ferulic acid and its oligomers. J. Sci. Food Agr., 2008, 88(9), 1494- 1511.

[37] Cai, Y.; Luo, Q.; Sun, M.; Corke, H. Antioxidant activity and phe- nolic compounds of 112 traditional Chinese medicinal plants asso- ciated with anticancer. Life Sci., 2004, 74(17), 2157-2184.

[38] Jakobek, L.; Seruga, M.; Novak, I.; Medvidovic-Kosanovic, M. Flavonols, phenolic acids and antioxidant activity of some red fruits. Deut. Lebensm-Rundsch., 2007, 103(8), 369378.

[39] Papetti, A.; Daglia, M.; Aceti, C.; Sordelli, B.; Spini, V.; Caraz- zone, C.; Gazzani, G. Hydroxycinnamic acid derivatives occurring in Cichorium endivia vegetables. J. Pharmaceut. Biomed., 2008, 48(2), 472-476.

[40] Manach, C.; Williamson, G.; Morand, C.; Scalbert, A.; Rémésy, C. Bioavailability and bioefficacy of polyphenols in humans. I. Re- view of 97 bioavailability studies. Am. J. Clin. Nutr., 2005, 81(1), 230 S.

[41] Kroon, P.A.; Williamson, G. Hydroxycinnamates in plants and food: current and future perspectives. J. Sci. Food Agr., 1999, 79(3), 355-361.

[42] Chuang, J.Y.; Tsai, Y.Y.U.; Chen, S.S.U.C.; Hsieh,

T.J.Y.E.;

Chung, J.G. Induction of G0/G1 arrest and apoptosis by 3hydroxycinnamic acid in human cervix epithelial carcinoma (HeLa) cells. In Vivo, 2005, 19(4), 683.

[43] Shamim, U.; Hanif, S.; Ullah, M.F.; Azmi, A.S.; Bhat, S.H.; Hadi,

S.M. Plant polyphenols mobilize nuclear copper in human periph- eral lymphocytes leading to oxidatively generated
DNA breakage: implications for an anticancer mechanism. Free Radic. Res., 2008, 42(8), 764-772.

[44] Domenico, F.D.; Foppoli, C.; Coccia, R.; Perluigi, M. Antioxidants in cervical cancer: chemopreventive and chemotherapeutic effects of polyphenols. Biochim. Biophys. Acta, 2012, 1822(5), 737-747.

[45] Touaibia, M.; Jean-Francois, J.; Doiron, J. Caffeic acid, a versatile pharmacophore: an overview. Mini Rev. Med. Chem., 2011, 11(8), 695-713.

[46] Venkateswarlu, S.; Ramachandra, M.S.; Krishnaraju, A.V.; Trimur- tulu, G.; Subbaraju, G.V. Antioxidant and antimicrobial activity evaluation of polyhydroxycinnamic acid ester derivatives. Indian J. Chem. B, 2006, 45(1), 252-.

[47] Firuzi, O.; Giansanti, L.; Vento, R.; Seibert, C.; Petrucci, R.; Mar- rosu, G.; Agostino, R.; Saso, L. Hypochlorite scavenging activity of hydroxycinnamic acids evaluated by a rapid microplate method 
based on the measurement of chloramines. J. Pharm. Pharmacol., 2003, 55(7), 1021-1027.

[48] Sud'Ina, G.F.; Mirzoeva, O.K.; Pushkareva, M.A.; Korshunova, G.A.; Sumbatyan, N.V.; Varfolomeev, S.D. Caffeic acid phenethyl ester as a lipoxygenase inhibitor with antioxidant properties. FEBS Lett., 1993, 329(1-2), 2124.

[49] Chen, J.H.; Ho, C.T. Antioxidant activities of caffeic acid and its related hydroxycinnamic acid compounds. J. Agric. Food Chem., 1997, 45(7), 2374-2378.

[50] Kim, D.O.; Lee, C.Y. Comprehensive study on vitamin C equiva- lent antioxidant capacity (VCEAC) of various polyphenolics in scavenging a free radical and its structural relationship. CRC Crit. Rev. Food Sci. Nutr., 2004, 44(4), 253-273.

[51] Youdim, K.A.; Shukitt-Hale, B.; MacKinnon, S.; Kalt, W.; Joseph,

J.A. Polyphenolics enhance red blood cell resistance to oxidative stress: in vitro and in vivo1. BBA-Gen. Subjects, 2000, 1523(1), 117-122.

[52] Siquet, C.; Paiva-Martins, F.; Lima, J.L.F.C.; Reis, S.; Borges, F. Antioxidant profile of dihydroxy-and trihydroxyphenolic acids-a structure-activity relationship study. Free Radic. Res., 2006, 40(4), 433-442.

[53] Kim, S.R.; Kim, Y.C. Neuroprotective phenylpropanoid esters of rhamnose isolated from roots of Scrophularia buergeriana. Phyto- chemistry, 2000, 54(5), 503-509.

[54] Mook-Jung, I.; Kim, H.; Fan, W.; Tezuka, Y.; Kadota, S.; Nishijo, H.; Jung, M.W. Neuroprotective effects of constituents of the ori- ental crude drugs, Rhodiola sacra, $R$. sachalinensis and Tokaku- joki-to, against beta-amyloid toxicity, oxidative stress and apopto- sis. Biol. Pharm. Bull., 2002, 25(8), 1101-1104.

[55] Garrido, J.; Gaspar, A.; Garrido, E.M.; Miri, R.; Tavakkoli, M.; Pourali, S.; Saso, L.; Borges, F.; Firuzi, O. Alkyl esters of hy- droxycinnamic acids with improved antioxidant activity and lipo- philicity protect PC12 cells against oxidative stress. Biochimie, 2012.

[56] Rice-Evans, C.A.; Miller, N.J.; Paganga, G. Structureantioxidant activity relationships of flavonoids and phenolic acids. Free Radic. Biol. Med., 1996, 20(7), 933-956.

[57] Sato, Y.; Itagaki, S.; Kurokawa, T.; Ogura, J.; Kobayashi, M.; Hirano, T.; Sugawara, M.; Isek, K. In vitro and in vivo antioxidant properties of chlorogenic acid and caffeic acid. Int. J. Pharm., 2011, 403, 136-138.

[58] Clifford, M.N.; Johnston, K.L.; Knigh, S.; Kuhnert, N. Hierarchical scheme for LC-MS Identification of chlorogenic acids. J. Agric. Food chem., 2003, 51(10), 2900-2911.

[59] Farah, A.; Monteiro, M.; Donangelo, C.M.; Lafay, S. Chlorogenic acids from green coffee extract are highly bioavailable in humans. J. Nutr., 2008, 138(12), 2309.

[60] Bouayed, J.; Rammal, H.; Dicko, A.; Younos, C.; Soulimani, R. Chlorogenic acid, a polyphenol from Prunus domestica (Mira- belle), with coupled anxiolytic and antioxidant effects. J. Neurol. Sci., 2007, 262, 77-84.

[61] Kweon, M.H.; Hwang, H.J.; Sung, H.C. Identification and antioxi- dant activity of novel chlorogenic acid derivatives from Bamboo (Phyllostachys edulis). J. Agric. Food Chem., 2001, 49 (20), 46464655.

[62] Abdullah, Y.; Schneider, B.; Petersen, M. Occurrence of rosmarinic acid, chlorogenicacid and rutin in Marantaceae species. Phyto- chem.Lett., 2008, 1, 199-203.

[63] Bowlers, B.L.; Miller, A.J. Caffeic acid activity against clostridium botulinum spores. J. Food Sci., 1994, 59(4), 905908.
[64] Ma, C.M.; Kully, M.; Khan, J.K.; Hattori, M.; Daneshtalab, M. Synthesis of chlorogenic acid derivatives with promising antifungal activity. Bioorgan. Med. Chem., 2007, 15, 68306833.

[65] Jassim, S.A.A.; Naji, M.A. Novel antiviral agents: a medicinal plant perspective. J. Appl. Microbiol., 2003, 95(3), 412-413.

[66] Wang, G.F.; Shi, L.P.; Ren, Y.D.; Liu, Q.F.; Liu, H.F.; Zhang, R.J.; Li, Z.; Zhu, F.H.; He, P.L.; Tang, W.; Tao, P.Z.; Li, C.; Zhao, W.M.; Zuo, J.P. Anti-hepatitis B virus activity of chlorogenic acid, quinic acid and caffeic acid in vivo and in vitro. Antivir. Res., 2009, 83, 186-190.

[67] Li, Y.; Shi, W.; Li, Y.; Zhou, Y.; Hu, X.; Song, C.; Ma, H.; Wang, C.; Li, Y. Neuroprotective effects of chlorogenic acid against apop- tosis of PC12 cells induced by methylmercury. Environl. Toxicol. Pharm., 2008, 26 13-21.

[68] Paynter, N.P.; Yeh, H.C.; Voutilainen, S.; Schmidt, M.I.; Heiss, G.; Folsom, A.R.; Brancati, F.L.; Linda Kao, W.H. Coffee and Sweet- 
ened Beverage Consumption and the Risk of Type 2 Diabetes Mel- litus. Am. J. Epidemiol., 2005, 164(11), 1075-1084.

[69] Karthikesan, K.; Pari, L.; Menon, V.P. Protective effect of tetrahy- drocurcumin and chlorogenicacid against streptozotocin- nicotinamide generated oxidative stress induced diabetes. J. Funct. Food., 2010, 2(2), 134-142.

[70] Rodriguez de Sotillo, D.V.; Hadley, M. Chlorogenic acid modifies plasma and liver concentrations of: cholesterol, triacylglycerol, and minerals in (fa/fa) Zucker rats. J. Nutr. Biochem., 2002, 13(12), 717-726.

[71] Natarajan, K.; Singh, S.; Burke, T.R.; Grunberger, D.; Aggarwal,

B.B. Caffeic acid phenethyl ester is a potent and specific inhibitor of activation of nuclear transcription factor NFkappa B. Natl. A. Sci., 1996, 93(17), 9090.

[72] Balasundrama, N.; Sundramb, K.; Samman, S. Phenolic com- pounds in plants and agri-industrial by-products: Antioxidant activ- ity, occurrence, and potential uses. Food Chem., 2006, 99(1), 191- 203.

[73] Wang, C.C.; Chen, L.G.; Lee, L.T.; Yang, L.L. Effects of 6gingerol, an antioxidant from ginger, on inducing apoptosis in hu- man leukemic HL-60 cells. In Vivo, 2003 17(16), 641-645.

[74] Chunga, W.Y.; Jung, Y.J.; Surhe, Y.J.; Lee, S.S.; Park, K.K. Antioxidative and antitumor promoting effects of [6]-paradol and its homologs. Mutat. Res-Gen. Tox. En., 2001, 496(12), 199-206.

[75] Suresh, K.; Manoharan, S.; Vijayaanand, M.A.; Sugunadevi, G. Chemopreventive and antioxidant efficacy of (6)paradol in 7,12- dimethylbenz(a)anthracene induced hamster buccal pouch carcino- genesis. Pharmacol. Rep., 2010, 62(6), 1178-1185.

[76] Robbins, R.J. Phenolic acids in foods: an overview of analytical methodology. J. Agric. Food Chem., 2003, 51(10), 2866-2887.

[77] Siger, A.; Nogala-kalucka, M.; Lampart-szczapa, E. The content and antioxidant activity of phenolic compounds in cold-pressed plant oils. J. Food Lipids, 2008, 15, 137149.

[78] Shahidi, F.; Chandrasekara, A. Hydroxycinnamates and their in vitro and in vivo antioxidant activities. Phytochem. Rev., 2010, 9, 147-170.

[79] Nardini, M.; D'Aquino, M.; Tomassi, G.; Gentili, V.; Di Felice, M.; Scaccini, C. Inhibition of human low-density lipoprotein oxidation by caffeic acid and other hydroxycinnamic acid derivatives. Free Radic. Biol. Med., 1995, 19(5), 541-552.

[80] Chlop íková, S.; Psotova, J.; Miketova, P.; Sousek, J.; Lichnovsky, V.; Simánek, V. Chemoprotective effect of plant phenolics against anthracycline induced toxicity on rat cardiomyocytes Part II. caf- feic, chlorogenic and rosmarinic acids. Phytother. Res., 2004, 18(5), 408-413.

[81] Zhu, H.; Chen, S.; Hao, S.; Zhang, Z.; Wang, W.; Yao, S. Double roles of hydroxycinnamic acid derivatives in protection against lysozyme oxidation. BBA-Gen. Subjects, 2006, 1760(12), 18101818.

[82] Gaspar, A.; Garrido, E.M.; Esteves, M.; Quezada, E.; Milhazes, N.; Garrido, J.; Borges, F. New insights into the antioxidant activity of hydroxycinnamic acids: Synthesis and physicochemical characteri- zation of novel halogenated derivatives. Eur. J. Med. Chem., 2009, 44(5), 2092-2099.

[83] Wu, W.M.; Lu, L.; Long, Y.; Wang, T.; Liu, L.; Chen, Q.;

Wang,

$R$. Free radical scavenging and antioxidative activities of caffeic acid phenethyl ester (CAPE) and its related compounds in solution and membranes: A structure- activity insight. Food Chem., 2007, 105(1), 107-115.

[84] Foley, S.; Navaratnam, S.; McGarvey, D.J.; Land, E.J.; Truscott, T.G.; Rice-Evans, C.A. Singlet oxygen quenching and the redox properties of hydroxycinnamic acids. Free Radic. Biol. Med., 1999, 26(9-10), 1202-1208.

[85] Zhang, J.; Stanley, R.A.; Adaim, A.; Melton, L.D.; Skinner, M.A. Free radical scavenging and cytoprotective activities of phenolic antioxidants. Mol. Nutr. Food Res., 2006, 50(11), 996-1005.

[86] Gaspar, A.; Martins, M.; Silva, P.; Garrido, E.M.; Garrido, J.; Fi- ruzi, O.; Miri, R.; Saso, L.; Borges, F. Dietary phenolic acids and derivatives. Evaluation of the antioxidant activity of sinapic acid and its alkyl esters. J. Agric. Food Chem., 2010.

[87] de la Puerta, R.; Gutierrez, V.R.; Hoult, J.R.S. Inhibition of leuko- cyte 5-lipoxygenase by phenolics from virgin olive oil. Biochem. pharmacol., 1999, 57(4), 445-449.

[88] Chanda, S.; Dave, R. In vitro models for antioxidant activity evaluation and some medicinal plants possessing antioxidant prop- erties: An overview. Afr. J. Microbiol. Res., 2009, 3, 981-996. 
[89] Badarinath, A.V.; Rao, K.M.; Chetty, C.M.S.; Ramkanth, S.; Ra- jan, T.V.S.; Gnanaprakash, K. A review on in-vitro antioxidant methods: comparisions, correlations and considerations. Int. J. Pharm. Tech. Res., 2010, 2(2), 12761285.

[90] Singh, S.; Singh, R.P. In vitro methods of assay of antioxidants: an overview. Food Rev. Int., 2008, 24(4), 392-415.

[91] Magalhaes, L.M.; Segundo, M.A.; Reis, S.; Lima, J.L.F.C. Methodological aspects about in vitro evaluation of antioxidant proper- ties. Anal. Chim. Acta, 2008, 613(1), 1-19.

[92] Craft, B.D.; Kerrihard, A.L.; Amarowicz, R.; Pegg, R.B. Phenolbased antioxidants and the in vitro methods used for their assess- ment. Compr. Rev. Food Sci. Food Safety, 2012, 11(2), 148-173.

[93] Newman, D.J.; Cragg, G.M. Natural products as sources of new drugs over the 30 years from 1981 to 2010. J. Nat. Prod., 2012, 75(3), 311-335.

[94] Sharma, P. Cinnamic acid derivatives: A new chapter of various pharmacological activities. J. Chem. Pharm. Res., 2011, 3(2), 403- 423.

[95] Testa, B.; Kier, L.B. The concept of molecular structure in struc- ture-activity relationship studies and drug design. Med. Res. Rev., 1991, 11(1), 35-48.

[96] Andricopulo, A.D.; Montanari, C.A. Structure-activity relation- ships for the design of small-molecule inhibitors. Mini Rev. Med. Chem., 2005, 5(6), 585-593.

[97] Camacho, R.; Pereira, M.; Costa, V.S.; Fonseca, N.A.; Adriano, C.; Simaues, C.J.; Brito, R.M. A relational learning approach to struc- ture-activity relationships in drug design toxicity studies. J. Integ. bioinform., 2011, 8(3), 182.

[98] Koehn, F.E.; Carter, G.T. The evolving role of natural products in drug discovery. Nat. Rev. Drug Discov., 2005, 4, 206-220.

[99] Cos, P.; Ying, L.; Calomme, M.; Hu, J.P.; Cimanga, K.; Van Poel, B.; Pieters, L.; Vlietinck, A.J.; Berghe, D.V. Structureactivity re- lationship and cassification of flavonoids as inhibitors of xanthine oxidase and superoxide scavengers. J. Nat. Prod., 1998, 61(1), 71- 76.

[100] Ordoudi, S.A.; Tsimidou, M.Z. Crocin bleaching assay (CBA) in structure-radical scavenging activity studies of selected phenolic compounds. J. Agric. Food Chem., 2006, 54(25), 9347-9356.

[101] Cheng, J.C.; Dai, F.; Zhou, B.; Yang, L.; Liu, Z.L. Antioxidant activity of hydroxycinnamic acid derivatives in human low density lipoprotein: mechanism and structure-activity relationship. Food Chem., 2007, 104(1), 132-139.

[102] Natella, F.; Nardini, M.; Di Felice, M.; Scaccini, C. Benzoic and cinnamic acid derivatives as antioxidants: structure-activity rela- tion. J. Agric. Food Chem., 1999, 47(4), 1453-1459.

[103] Nenadis, N.; Zhang, H.Y.; Tsimidou, M.Z. Structureantioxidant activity relationship of ferulic acid derivatives: Effect of carbon side chain characteristic groups. J. Agric. Food Chem., 2003, 51(7), 1874-1879.

[104] Graf, E. Antioxidant potential of ferulic acid. Free Radic. Biol. Med., 1992, 13(4), 435-448.

[105] Barone, E.; Calabrese, V.; Mancuso, C. Ferulic acid and its thera- peutic potential as a hormetin for age-related diseases. Biogeron- tology, 2009, 10(2), 97-108.

[106] Esteves, M.; Siquet, C.; Gaspar, A.; Rio, V.; Sousa, J.B.; Reis, S.; Marques, M.P.M.; Borges, F. Antioxidant versus cytotoxic proper- ties of hydroxycinnamic acid derivativesa new paradigm in phe- nolic research. Arch. Pharm., 2008, 341(3), 164-173.

[107] Barbakadze, V.; Kemertelidze, E.; Targamadze, I.; Mulkidzhanyan, K.; Kemink, J.; Berg, A.; Beukelman, K.; Usov, A. Poly[3-(3,4- dihydroxyphenyl)glyceric acid] from stems of Symphytum asperum and S. caucasicum. Chem. Nat. Compd., 2005, 41(4), 374-377.

[108] Dziedzic, S.Z.; Hudson, B.J.F. Phenolic acids and related compounds as antioxidants for edible oils. Food Chem., 1984, 14(1), 45-51.

[109] Silva, F.A.M.; Borges, F.; Guimarães, C.; Lima, J.L.F.C.; Matos, C.; Reis, S. Phenolic acids and derivatives: studies on the relation- ship among structure, radical scavenging activity, and physico- chemical parameters. J. Agric. Food Chem., 2000, 48(6), 21222126.

[110] Mathiesen, L.; Malterud, K.E.; Sund, R.B. Hydrogen bond forma- tion as basis for radical scavenging activity: A structure-activity study of C-methylated dihydrochalcones from Myrica gale and structurally related acetophenones. Free Radic. Biol. Med., 1997, 22(1-2), 307-311. 
[111] Castelluccio, C.; Paganga, G.; Melikian, N.; Paul Bolwell, G.; Pridham, J.; Sampson, J.; Rice-Evans, C. Antioxidant potential of intermediates in phenylpropanoid metabolism in higher plants. FEBS Lett., 1995, 368(1), 188-192.

[112] Hansch, C.; Leo, A.; Hoekman, D. Ferulic acid: exploring QSAR: hydrophobic, electronic, and steric constants, American Chemical Society Washington, DC, 1995.

[113] Arora, A.; Nair, M.G.; Strasburg, G.M. Structure-activity relation- ships for antioxidant activities of a series of flavonoids in a liposo- mal system. Free Radic. Biol. Med., 1998, 24(9), 1355-1363.

[114] Laranjinha, J.; Vieira, O.; Almeida, L.; Modeira, V. Inhibition of metmyoglobin/H2O2-dependent low density lipoprotein lipid per- oxidation by naturally occurring phenolic acids. Biochem. Pharma- col., 1996, 51(4), 395402.

[115] Cos, P.; Rajan, P.; Vedernikova, I.; Calomme, M.; Pieters, L.; Vlietinck, A.J.; Augustyns, K.; Haemers, A.; Berghe, D.V. In vitro antioxidant profile of phenolic acid derivatives. Free Radic. Res., 2002, 36(6), 711-716.

[116] Hung, T.M.; Na, M.K.; Thuong, P.T.; Su, N.D.; Sok, D.E.;

Song,

K.S.; Seong, Y.H.; Bae, K.H. Antioxidant activity of caffeoyl quinic acid derivatives from the roots of Dispora asper wall. J. Ethnopharmacol., 2006, 108(2), 188-192.

[117] Fagerlund, A.; Sunnerheim, K.; Dimberg, L.H. Radicalscavenging and antioxidant activity of avenanthramides. Food Chem., 2009, 113(2), 550-556.

[118] Meng, L.; Lozano, Y.F.; Gaydou, E.M.; Li, B. Antioxidant activi- ties of polyphenols extracted from Perilla frutescens varieties. Molecules, 2009, 14(1), 133-140.

[119] Kancheva, V.D. Ed.; A.A. Farouqui. Nova Sci., Publishers Inc, USA, 2012, pp. 1-45.

[120] Kancheva, V.D. Phenolic antioxidants-radical scavenging and chain breaking activity: a comparative study. Eur. J. Lipid Sci. Technol., 2009, 111, 1072-1089.

[121] Teixeria, J.; Soares, P.; Benfeito, S.; Gaspar, A.; Garrido, J.; Mur- phy, M.P.; Borges, F. Rational discovery and development of a mi- tochondria-targeted antioxidant based on cinnamic acid scaffold. Free Radic. Res., 2012, 46(5), 600-611.

[122] Rakotondramanana, D.L.A.; Delomenède, M.; Baltas, M.; Duran, H.; Bedos-Belval, F.; Rasoanaivo, P.; NegreSalvayre, A.; Gor- nitzka, H. Synthesis of ferulic ester dimers, functionalisation and biological evaluation as potential antiatherogenic and antiplasmo- dial agents. Bioorgan. Med. Chem., 2007, 15(18), 6018-6026.

[123] Foti, M.; Ruberto, G. Kinetic solvent effects on phenolic antioxi- dants determined by spectrophotometric measurements. J. Agric. Food Chem., 2001, 49(1), 342348.

[124] Marimuthu, S.; Adluri, R.S.; Venugopal, P.M. Ferulic acid: thera- peutic potential through its antioxidant property. $J$. Clin. Biochem. Nutr., 2007, 40(2), 92-100.

[125] Kikuzaki, H.; Hisamoto, M.; Hirose, K.; Akiyama, K.; Taniguchi,

$\mathrm{H}$. Antioxidant properties of ferulic acid and its related compounds.

J. Agric. Food Chem., 2002, 50(7), 2161-2168

[126] Menezes, J.C.; Kamat, S.P.; Cavaleiro, J.A.S.; Gaspar, A.; Garrido, J.; Borges, F. Synthesis and antioxidant activity of long chain alkyl hydroxycinnamates. Eur. J. Med. Chem., 2011.

[127] Materska, M.; Perucka, I. Antioxidant activity of the main phenolic compounds Isolated from hot pepper fruit (Capsicum annuum L.). J. Agric. Food Chem., 2005, 53, 1750-1756.

[128] Kortenska, V.D.; Velikova, M.P.; Yanishlieva, N.V.; Totzeva,
I.R.; Bankova, V.S.; Marcucci, M.C. Kinetics of lipid oxidation in the presence of cinnamic acid derivatives. Eur. J. Lipid Sci. Technol., 2002, 104, 19-28.

[129] Bores, W.; Kazazic, S.P.; Michel, C.; Kortenska, V.D.; Stettmaier, K.; Klasinc, L. Methoxyphenols-antioxidant principles in food plants and species: pulse radiolysis, EPR spectroscopy, and density functional theory calculations. Int. J. Quantum Chem., 2002, 90, 969-979.

[130] Karamac, M.; Kosiñska, A.; Pegg, R.B. Comparison of radicalscavenging activities for selected phenoilc acids. Pol. J. Food Nutr. Sci. , 2005, 14/55(2), 165-170.

[131] Fotso Fondja Yao, C.B.; Al Zereini, W.; Fotso, S.; Anke, H.; Laatsch, H. Aqabamycins A-G: novel nitro maleimides from a ma- rine Vibrio species: II. structure elucidation. J. Antibiotics, 2010, 63(6), 303-308.

[132] Iwasaki, Y.; Nomoto, M.; Oda, M.; Mochizuki, K.; Nakano, Y.; Ishii, Y.; Ito, R.; Saito, K.; Umemura, T.; Nishikawa, A.; Naka- zawa, H. Characterization of nitrated phenolic compounds for their 
anti-oxidant, pro-oxidant, and nitration activities. Arch. Biochem. Biophys., 2011, 513, 10-18.

[133] Del Prete, E.; Lutz, T.A.; Scharrer, E. Inhibition of glucose oxida- tion by alpha-cyano-4-hydroxycinnamic acid stimulates feeding in rats. Physiol. Behav., 2004, 80(4), 489-498.

[134] Petrucci, R.; Astolfi, P.; Greci, L.; Firuzi, O.; Saso, L.; Marrosu, G. A spectroelectrochemical and chemical study on oxidation of hy- droxycinnamic acids in aprotic medium. Electrochim. Acta, 2007, 52(7), 2461-2470.

[135] Hrádková, I.; Smidrkal, J.; Filip, V.; Merkl, R.; Kabrdová, E. Anti- oxidant stability of phenolic acids and their esters. Czech. J. Food Sci., 2009, 27, S41-S44.

[136] Fixon-Owoo, S.; Levasseur, F.; Williams, K.; Sabado, T.N.; Lowe, M.; Klose, M.; Joffre Mercier, A.; Fields, P.; Atkinson, J. Prepara- tion and biological assessment of hydroxycinnamic acid amides of polyamines. Phytochemistry, 2003, 63(3), 315-334.

[137] Stankova, I.; Spasova, M. Hydroxycinnamic acid amides with oxazole-containing amino acid: synthesis and antioxidant activity. Z. Naturforsch. C., 2009, 64(3-4), 176-178.

[138] Couteau, D.; McCartney, A.L.; Gibson, G.R.; Williamson, G.; Faulds, C.B. Isolation and characterization of human colonic bacte- ria able to hydrolyse chlorogenic acid. J. App. Microbiol., 2001, 90, 873-881.

[139] Hung, C.C.; Tsai, W.J.; Kuo, L.M.Y.; Kuo, Y.H. Evaluation of caffeic acid amide analogues as anti-platelet aggregation and anti- oxidative agents. Bioorgan. Med. Chem., 2005, 13(5), 1791-1797.

[140] Stankova, I.; Chuchkov, K.; Shishkov, S.; Kostova, K.; Mukova, L.; Galabov, A.S. Synthesis, antioxidative and antiviral activity of hydroxycinnamic acid amides of thiazole containing amino acid. Amino acids, 2009, 37(2), 383-388.

[141] Laguerre, M.; Lecomte, J.; Villeneuve, P. Evaluation of the ability of antioxidants to counteract lipid oxidation: existing methods, new trends and challenges. Prog. Lipid Res., 2007, 46, 244-282.

[142] Lekse, J.M.; Xia, L.; Stark, J.; Morrow, J.D.; May, J.M. Plant catechols prevent lipid peroxidation in human plasma and erythro- cytes. Mol. Cell. Biochem., 2001, 226,89-95.

[143] Soobrattee, M.A.; Neergheen, V.S.; Luximon-Ramma, A.; Aruoma, O.; Bahorun, T. Phenolics as potential antioxidant thera- peutic agents: mechanism and actions. Mutat. ResFund. Mol. M., 2005, 579(1-2), 200-213.

[144] Chevion, S.; Roberts, M.A.; Chevion, M. The use of cyclic volt- ammetry for the evaluation of antioxidant capacity. Free Radic. Biol. Med., 2000, 28, 860-870.

[145] Blasco, A.J.; Crevillén, A.G.; González, M.C.; Escarpa, A. Direct electrochemical sensing and detection of natural antioxidants and antioxidant capacity in vitro systems. Electroanal., 2007, 19, 2275 $-2286$.

[146] Galato, D.; Ckless, K.; Susin, M.F.; Giacomelli, C.; Spinelli, A. Antioxidant capacity of phenolic and related compounds: correla- tion among electrochemical, visible spectroscopy methods and structure-antioxidant activity. Redox Rep., 2001, 6(4), 243-250.

[147] Roleira, F.M.F.; Siquet, C.; Orrù, E.; Garrido, E.M.; Garrido, J.; Milhazes, N.; Podda, G.; Paiva-Martins, F.; Reis, S.; Carvalho,

R.A. Lipophilic phenolic antioxidants: correlation between antioxi- dant profile, partition coefficients and redox properties. Bioorgan. Med. chem., 2010, 18(16), 58165825 .

[148] Zhao, Z.; Moghadasian, M.H. Bioavailability of hydroxycinna- mates: a brief review of in vivo and in vitro studies. Phytochem. Rev., 2010, 9(1), 133-145.

[149] Gilgun-Sherki, Y.; Melamed, E.; Offen, D. Oxidative stress induced-neurodegenerative diseases: the need for antioxidants that penetrate the blood brain barrier. Neuropharmacology, 2001, 40(8), 959-975.

[150] Andjelkovic', M.; Van Camp, J.; De Meulenaer, B.; Depaemelaere, G.; Socaciu, C.; Verloo, M.; Verhe, R. Ironchelation properties of phenolic acids bearing catechol and galloyl groups. Food Chem., 2006, 98, 23-31.

[151] Brown, J.E.; Khodr, H.; Hider, R.C.; Rice-Evans, C.A. Structural dependence of flavonoid interactions with $\mathrm{Cu}^{2+}$ ions: implications for their antioxidant properties Biochem. J., 1998, 330, 1173-1178.

[152] Lapouge, C.; Cornard, J.P. Reaction pathways involved in the mechanism of AllII chelation with caffeic acid: catechol and car- boxylic functions competition. ChemPhysChem., 2007, 8, 473-479.

[153] Psotová, J.; Lasovsky, J.; Vicar, J. Metal-chelating properties, electrochemical behavior, scavenging and cytoprotective activities of six natural phenolics. Biomed. Papers, 2003, 147(2), 147-153. 
[154] Kalinowska, M.; Laderiere, B.; Champagne, P.; KowczykSadowy, M.; Lewandowski, W. $\mathrm{Mn}$ (II), $\mathrm{Cu}(\mathrm{II})$ and $\mathrm{Cd}(\mathrm{II}) \mathrm{p}$ coumarates: FT- IR, FT-Raman, $1 \mathrm{H}$ and $13 \mathrm{C} \mathrm{NMR}$ and thermogravimetric studies. Spectrochim. Acta A, 2013, 103, 264-271.

[155] Yang, B.; Chen, F.; Hua, Y.; Huang, S.S.; Lin, S.; Wen, L.;

Jiang,

Y. Prooxidant activities of quercetin, p-courmaric acid and their de- rivatives analysed by quantitative structureactivity relationship. Food Chem., 2012, 131, 508-512.

[156] Azmi, A.S.; Bhat, S.H.; Hanif, S.; Hadi, S.M. Plant polyphenols mobilize endogenous copper in human peripheral lymphocytes leading to oxidative DNA breakage: a putative mechanism for anti- cancer properties. FEBS Lett., 2006, 580(2), 533-538.

[157] Bhat, S.H.; Azmi, A.S.; Hadi, S.M. Prooxidant DNA breakage induced by caffeic acid in human peripheral lymphocytes: in- volvement of endogenous copper and a putative mechanism for anticancer properties. Toxicol. appl. pharm., 2007, 218(3), 249255.

[158] Sakihama, Y.; Cohen, M.F.; Grace, S.C.; Yamasaki, H. Plant phe- nolic antioxidant and prooxidant activities: phenolics-induced oxi- dative damage mediated by metals in plants. Toxicology, 2002, 177(1), 67-80.

[159] Zheng, L.F.; Dai, F.; Zhou, B.; Yang, L.; Liu, Z.L. Prooxidant activity of hydroxycinnamic acids on DNA damage in the presence of $\mathrm{Cu}$ (II) ions: mechanism and structure-activity relationship. Food Chem. Toxicol., 2008, 46(1), 149-156.

[160] Yamanaka, N.; Oda, O.; Nagao, S. Prooxidant activity of caffeic acid, dietary non-flavonoid phenolic acid, on $\mathrm{Cu}^{2+}$-induced low density lipoprotein oxidation. FEBS Lett., 1997, 405(2), 186-190.

[161] Medina, I.; Undeland, I.; Larsson, K.; Storrø, I.; Rustad, T.; Jacob- sen, C.; Kristinová, V.; Gallardo, J.M. Activity of caffeic acid in different i sh lipid matrices: A review. Food Chem., 2012, 131, 730-740.

[162] Maurya, D.K.; Devasagayam, T.P.A. Antioxidant and prooxidant nature of hydroxycinnamic acid derivatives ferulic and caffeic ac- ids. Food Chem. Toxicol., 2010, 48(12), 3369-3373.

[163] Bors, W.; Michel, C.; Saran, M. Inhibition of the bleaching of the carotenoid crocin. A rapid test for quantifying antioxidant activity. BBA-Lipids Lipid Metab., 1984, 796(3), 312-319.

[164] Apak, R.; Güçlü, K.; Demirata, B.; Özyürek, M.; Çelik, S.E.; Bektałoglu, B.; Berker, K.I.; Özyurt, D. Comparative evaluation of various total antioxidant capacity assays applied to phenolic com- pounds with the CUPRAC assay. Molecules, 2007, 12, 1496-1547.

[165] Benzie, I.F.F.; Strain, J.J. The ferric reducing ability of plasma (FRAP) as a measure of" antioxidant power": the FRAP assay. Anal. Biochem., 1996, 239(1), 70-76.

[166] Cao, G.; Alessio, H.M.; Cutler, R.G. Oxygen-radical absorbance capacity assay for antioxidants. Free Radic. Biol. Med., 1993, 14(3), 303-311.

[167] Ou, B.; Hampsch-Woodill, M.; Prior, R.L. Development and vali- dation of an improved oxygen radical absorbance capacity assay using fluorescein as the fluorescent probe. J. Agric. Food Chem., 2001, 49(10), 4619-4626.

[168] Miller, N.J.; Rice-Evans, C.A.; Davies, M.J.; Gopinathan, V.; Mil- ner, A. A novel method for measuring antioxidant capacity and its application to monitoring the antioxidant status in premature neo- nates. Clin. Sci., 1993, 84, 407412.

[169] Wayner, D.D.M.; Burton, G.W.; Ingold, K.U.; Locke, S. Quantita- tive measurement of the total, peroxyl radicaltrapping antioxidant capability of human blood plasma by controlled peroxidation: The important contribution made by plasma proteins. FEBS Lett., 1985, 187(1), 33-37.

[170] Pelegrini, R.; Proteggente, A.; Yang, M.; Rice-Evans, C. Antioxi- dant activity applying an improved ABTS radical cation decolori- zation assay. Free Radic. Biol. Med., 1999, 26(9-10), 1231-1237.

[171] Brand-Williams, W.; Cuvelier, M.E.; Berset, C. Use of a free radi- cal method to evaluate antioxidant activity. LWT-Food Sci. Tech-nol., 1995, 28(1), 25-30.

[172] Blois, M.S. Antioxidant determinations by the use of a stable free radical. Nat. Rev. Drug Discov., 1958, 181, 11991200.

[173] Smirnoff, N.; Cumbes, Q.J. Hydroxyl radical scavenging activity of compatible solutes. Phytochemistry, 1989, 28(4), 1057-1060.

[174] Beers, J.R.F.; Sizer, I.W. Colorimetric method for estimation of catalase. J. Biol. Chem., 1952, 195(1), 133-140.

[175] Kooy, N.W.; Royall, J.A.; Ischiropoulos, H.; Beckman, J.S. Per- oxynitrite-mediated oxidation of dihydrorhodamine 123. Free Radic. Biol. Med., 1994, 16(2), 149-156. 
[176] Wilkinson, F.; Helman, W.P.; Ross, A.B. Rate constants for the decay and reactions of the lowest electronically excited singlet state of molecular oxygen in solution. An expanded and revised compi- lation. J. Phys. Chem. Ref. Data, 1995, 24, 663-1021.

[177] Beauchamp, C.; Fridovich, I. Superoxide dismutase: improved assay and an assay applicable to polyacrylamide gels. Anal. Bio- chem. , 1971, 44, 276-287.

[178] Miller, H.M. A simplified method for the evaluation of antioxi- dants. J. Am. Oil Chem. Soc., 1971, 45, 91-98.

[179] Milde, J.; Elstner, E.F.; Graßmann, J. Synergistic effects of phe- nolics and carotenoids on human low-density lipoprotein oxidation. Mol. Nutr. Food Res., 2007, 51, 956961.

[180] Chigorimbo-Murefu, N.T.L.; Riva, S.; Burton, S.G. Lipasecatalysed synthesis of esters of ferulic acid with natural compounds and evaluation of their antioxidant properties. J. Mol. Catal. B-Enzym., 2009, 56(4), 277-282.

[181] Kylli, P.; Nousiainen, P.; Biely, P.; Sipilä, J.; Tenkanen, M.; Hei- nonen, M. Antioxidant potential of hydroxycinnamic acid glyco- side esters. J. Agric. Food Chem., 2008, 56(12).

[182] Karamac, M.; Bucinski, A.; Pegg, R.B.; Amarowicz, R. Antioxi- dant and antiradical activity of ferulates. Czech $\mathrm{J}$. Food Sci., 2005, 23(2), 64-68.
[183] Hsu, L.Y.; Lin, C.F.; Hsu, W.C.; Hsu, W.L.; Chang, T.C. Evaluation of polyphenolic acid esters as potential antioxidants. Biol. Pharm. Bull., 2005, 28(7), 1211-1215.

[184] Chalas, J.; Claise, C.; Edeas, M.; Messaoudi, C.; Vergnes, L.; Abella, A.; Lindenbaum, A. Effect of ethyl esterification of pheno- lic acids on low-density lipoprotein oxidation. Biomed. Pharma- cother., 2001, 55(1), 54-60.

[185] Silva, F.A.; Borges, F.; Ferreira, M.A. Effects of phenolic propyl esters on the oxidative stability of refined sunflower oil. J. Agric. Food Chem., 2001, 49(8), 39363941.

[186] Meyer, A.S.; Donovan, J.L.; Pearson, D.A.; Waterhouse, A.L.; Frankel, E.N. Fruit hydroxycinnamic acidsinhibit human low- density lipoprotein oxidation in vitro. J. Agr. Food Chem., 1998, 46(5), 1783-1787.

[187] Velikova, V.B.; Edrevab, A.M.; Tsoneva, T.D.; Jonesc, H.G. Sin- glet oxygen quenching by phenylamides and their parent com- pounds. Z. Naturforsch., 2007, 62c, 833-838.

[188] Spasova, M.; Kortenska Kancheva, V.; Totseva, I.; Ivanova, G.; Georgiev, L.; Milkova, T. Synthesis of cinnamoyl and hydroxycin- namoyl amino acid conjugates and evaluation of their antioxidant activity. J. Pept. Sci., 2006, 12(5), 369375.

[189] Rajan, P.; Vedernikova, I.; Cos, P.; Vanden Berghe, D.; Augustyns, K.; Haemers, A. Synthesis and evaluation of caffeic acid amides as antioxidants. Bioorg. Med. Chem. Lett., 2001, 11(2), 215-217. 